KEYWORDS

Physical infrastructure

Financing

Investments

Public sector

Private sector

Financial institutions

Statistical data

Comparative analysis

Latin america

Asia

Patricio Rozas

Staff member of the Natural

Resources and Infrastructure

Division, ECLAC

œ patricio.rozas@cepal.org
CEPAL REVIEW $101 \cdot$ AUGUST 2010

\section{Latin America: problems and challenges of infrastructure financing}

\author{
Patricio Rozas
}

$\mathrm{T}$ his article seeks to quantify basic infrastructure trends in the region, and assess the extent to which they have fallen behind those in Southeast Asian countries, which were clearly less developed than their Latin American counterparts in the late 1970s. The specific aim is to identify the main general characteristics of basic infrastructure development in Latin America, highlighting the problems faced by the investment process, with a view to identifying the main consequences of those problems and thus specify the challenges facing the region's countries. 


\section{I \\ Basic infrastructure development in Latin America}

Various empirical studies have found a positive and significant correlation between infrastructure investment and economic growth, without that necessarily indicating a direction of causality between the two variables (Rozas and Sánchez, 2004). The dynamic that underpins this relation is relatively clear, however: more readily available and better quality infrastructure services - telecommunications; road network and transport services; power generation, transmission and distribution; and the supply of drinking water and sanitation services - raise factor productivity and lower production costs. The resulting higher profitability stimulates investment and thus enhances potential GDP growth. Recent studies point out that shortcomings in road and telecommunication networks significantly raise transport and logistic costs generally, which are above international standards, thereby undermining the competitiveness of firms, industries, and entire economies (Guasch and Kogan, 2001; ECLAC, 2004).

In the 1990s, the Latin American infrastructure services sector underwent a major structural transformation that affected telecommunications, energy, health services and transport. Most of the region's countries abolished State monopolies and encouraged the private sector to participate in markets hitherto reserved for State enterprises, by removing the legal barriers to entry in certain segments of industry.

The redefinition of the State's role in infrastructure provision meant that most of the region's countries privatized the State firms in each sector (many of which were legally protected monopolies) and introduced institutional and legal regulatory frameworks. In many cases, regulatory bodies were set up to oversee the activities undertaken by the private firms in each sector.

The liberalization of infrastructure-service markets and the privatization of State enterprises allowed foreign competitors to enter the market, many of which brought with them new production techniques,

$\square$ The author gratefully acknowledges assistance provided by Mauro Gutiérrez, who helped compile and process the statistical data. technologies, and modes of business organization, which proved decisive for modernizing infrastructure and locally produced services. This modernization was crucial for obtaining higher gains from systemic competitiveness and attracting new investment flows into other productive sectors.

Despite the broad scope of these trends, the restructuring of services spawned a variety of models that differ not only between sectors, but also from one country to another in the same sector. This diversity reflects sharp differences stemming from market size and structure, the real degree of competition that can be introduced in each country and each service, price-setting processes, service coverage and quality, and even their environmental impacts.

Thus, between 1985 and 2007, most Latin American countries improved the coverage and quality of services that depend on the availability of physical infrastructure and networks. Over the last 10 years, the expansion has been spectacular in the cellular phone and Internet markets, where the region has achieved one of the highest development indices worldwide (Rozas, 2008a). The coverage of electricity services has also grown, and many ports have been modernized under concession schemes (Doerr and Sánchez, 2006). In contrast, there has been little change in coverage in the road segment (ECLAC, 2004; Fay and Morrison, 2005; Sánchez and Wilmsmeier, 2005).

Despite these improvements, which have improved conditions for economic development, the expanded coverage of infrastructure services has been insufficient, as will be discussed below.

If shortcomings in economic infrastructure, caused by problems of industrial organization in markets or physical shortcomings, are not already undermining Latin America's capacity to sustain growth, increase factor productivity and enhance the competitiveness of their economies and reduce poverty, they could certainly do so in the near future. The region needs to overcome the infrastructure constraint to assure conditions providing a sustainable basis for growth. This explains the need for investment in the sector. 
The divergent behaviour of infrastructure supply and demand is causing two main effects, which are worrying in themselves: (i) a widening gap between the region and other emerging economies; and (ii) a trend towards insufficient provision of infrastructure services.

\section{II}

\section{Infrastructure investment:}

\section{an unresolved challenge}

The main reason for the inadequate development of basic infrastructure in Latin America over the last two decades stems from the difficulties countries have faced in maintaining an adequate pace of investment in the sector's various activities.

The average annual investment rate in infrastructure in the leading Latin American economies fell from $3.7 \%$ to $2.2 \%$ and $1.5 \%$ of gross domestic product (GDP) in successive five-year periods 1980-1985, 19962001 and 2002-2006, respectively. This is a steep drop considering that, in the first five years of the 1980s, the region was hit by the balance of payments crisis and high levels of external debt, which drastically contracted aggregate demand, including investment. Accordingly, the parameter against which average investment in 1996-2001 and 2002-2006 is compared, namely the average value for the five-year period 1980-1985, was not very demanding, since it had been lowered by the crisis affecting the region in the first half of the decade. Nonetheless, average investment in the periods 1996-2001 and 2002-2006 still declined sharply in relation to that baseline value.

Figure 1 shows that the decline in infrastructure investment throughout the 1980-2006 period was particularly acute in the areas of energy and land transport, although the latter recovered somewhat in 2002-2006 compared to 1996-2001, rising from $0.36 \%$ to $0.45 \%$ of GDP on average for the countries in the sample. In contrast, investment in telecoms grew strongly in the second half of the 1990s compared to the early 1980 s, before falling back almost to the initial levels in 2002-2006.

FIGURE 1

Latin America: ${ }^{a}$ Investment in infrastructure areas as a percentage of GDP, 1980-1985, 1996-2001, 2002-2006

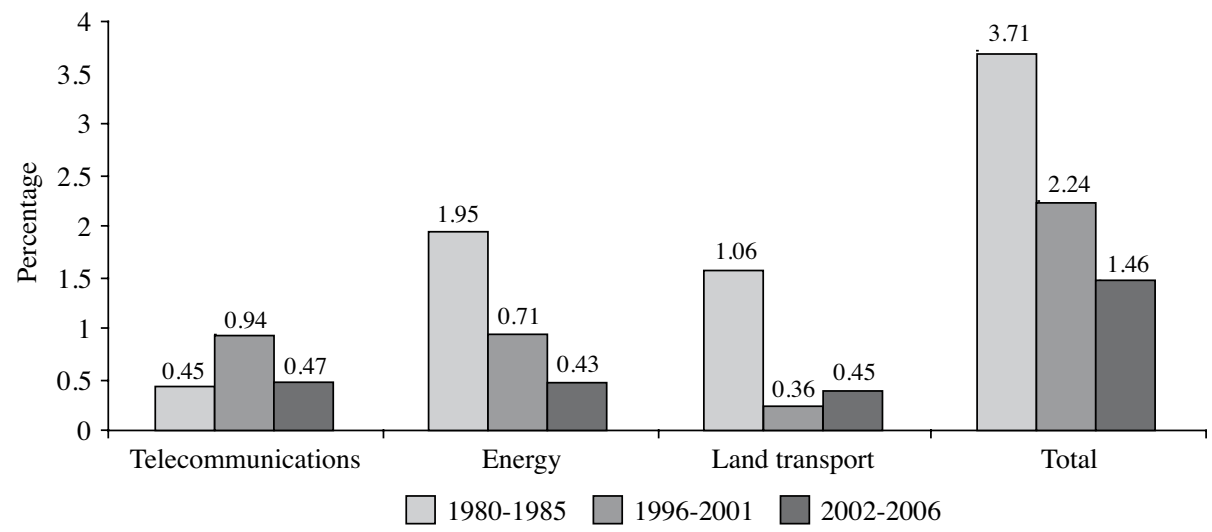

Source: For 1980-1985 and 1996-2001: César Calderón and Luis Servén, "Trends in infrastructure in Latin America, 1980-2001", Working Paper, No. 269, Santiago, Chile, Central Bank of Chile, September 2004. For 2002-2006: prepared by the author on the basis of figures from the World Bank and national statistics.

a Includes Argentina, Brazil, Chile, Colombia, Mexico, Peru and the Plurinational State of Bolivia. GDP: Gross domestic product. 
Much of the most recent economic literature on this subject has sought to explain the decline in investment flows into the sector. Explanatory factors suggested include public-expenditure cuts, the smaller contribution made by multilateral and bilateral lending agencies, and the reduction in private contributions. Discussion on the problems underlying the behaviour of the components of aggregate investment in infrastructure clearly remains an unresolved topic in the literature. Thus far, most analyses of the factors causing this situation have been conducted at the sector level, with very few considering the structural reforms implemented in the 1980s and the first five years of the 1990s. These should form the main focus of the analysis to identify the dynamic of the various ongoing processes both in the basic infrastructure industry and in the provision of related services.

An additional complication has been the partial nature of the information available —only approximations in some cases - and the tendency of some analysts to extrapolate situations that occur more intensively in the region's larger and more important countries, by assuming they are also valid for the other countries as part of more general trends, which is not necessarily the case.

On this point, the study made by Calderón and Servén (2004) helps to specify the varied trends that can be discerned in the region, behind the trend of aggregate investment variables. The two authors compare total investment in the early 1980 s with its counterpart in the first 10 years of this century in the leading economies of Latin America (Argentina, Brazil, Chile, Colombia, Mexico and Peru), together with the Plurinational State of Bolivia. The results obtained show that most countries suffered a sharp fall, which, in some cases, had barely been reversed by the early 1990s. The study sees Chile and Colombia as exceptions to that trend, since those countries saw significant growth in infrastructure investment during the decade (Calderón and Servén, 2004).

The data presented also show that total infrastructure investment fell off sharply in the largest economies (Brazil, Argentina and Mexico), where annual average expenditure on infrastructure halved in 1996-2001 compared to 1980-1985; but it rose in the smaller economies (Chile, Colombia, Peru and the Plurinational State of Bolivia), and particularly sharply in Chile and Colombia, by $5.6 \%$ and $5.8 \%$, respectively. In the ensuing period (2002-2006) the data show that the infrastructure investment rate fell even more sharply in all countries of the sample except
Mexico - even in those countries that had performed better in the preceding period (see figure 2).

The relevant questions therefore relate to this disparity. Why was infrastructure investment in the second half of the 1990s higher than in the early 1980s in some countries, but lower by half in others? Why does the infrastructure investment rate fall so sharply in Chile and Colombia, countries that displayed average rates of around $6 \%$ of their respective GDPs in the late 1990s? Is an infrastructure investment rate of $6 \%$ of GDP sufficient to satisfy the demands generated by the internal dynamics of economic growth and development?

Some analysts may seek to underestimate the observed reductions and highlight both the growth of GDP in the 2004-2007 period, way above the average for the two previous decades, with the possible maturity of markets in certain infrastructure industry areas, as the factors causing the decline, thereby validating the non-linear nature of the estimated relation between infrastructure and long-term growth (a positive but decreasing effect).

In Latin America, both arguments are debatable. Firstly, it is wrong to assume autonomous behaviour by infrastructure investment in relation to GDP growth, particularly in countries that have a major infrastructure deficit, without knowing the elasticity of output with respect to the provision of related services, which has been measured in numerous studies under various circumstances (Rozas and Sánchez, 2004); and particularly the close two-way causal relationship between the two variables detected by Canning and Pedroni (1999), when controlling for heterogeneous short-term interactions between infrastructure and GDP.

Secondly, the countries of the region are given an unduly short horizon in terms of the maturity of infrastructure service markets, as shown by a comparison of coverage and density indicators achieved by such services in Latin America, compared to their counterparts in more developed countries. It therefore seems more reasonable to seek factors to explain this decline by analysing the behaviour of the leading components of infrastructure investment. To do this general policy guidelines and the relevant measures need to be defined.

\section{Public investment}

Various studies have found a close correlation between the growth of primary public-sector deficits 


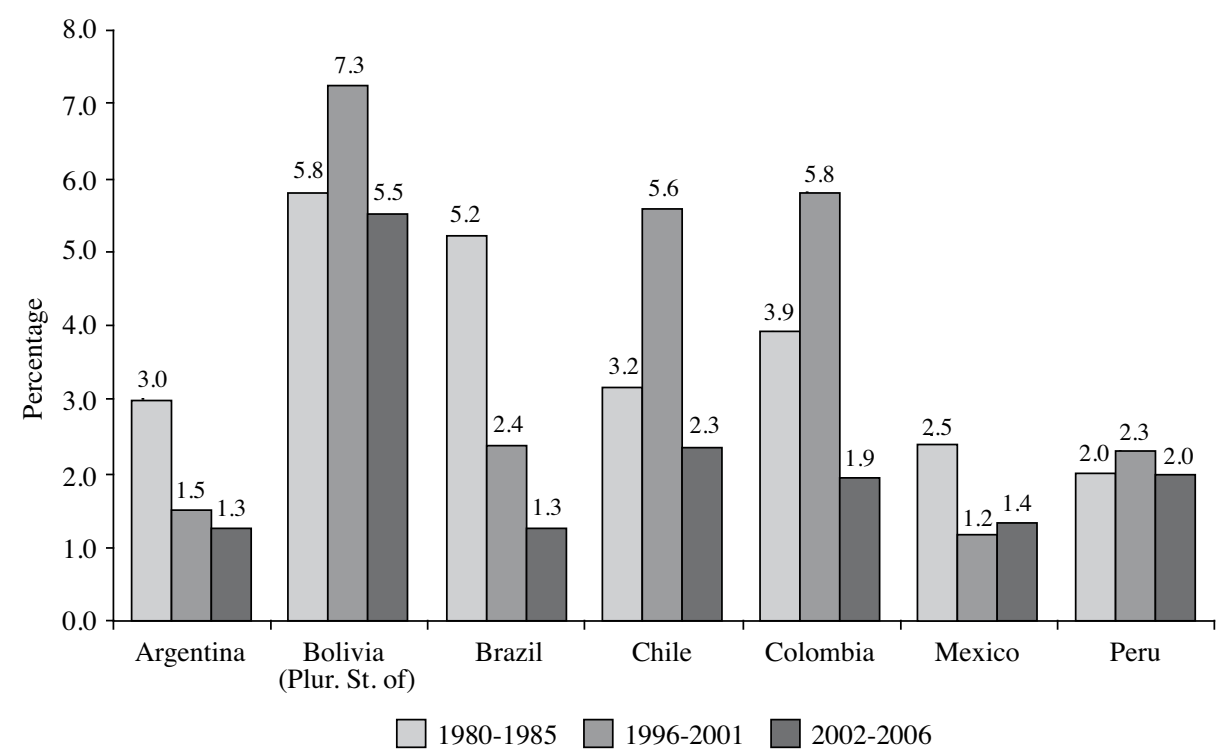

Source: For 1980-1985 and 1996-2001: César Calderón and Luis Servén, “Trends in infrastructure in Latin America, 1980-2001”, Working Paper, N 269, Santiago, Chile, Central Bank of Chile, September 2004. For 2002-2006: prepared by the author on the basis of figures from the World Bank and national statistics.

GDP: Gross domestic product.

and budget cuts for public investment generally and infrastructure in particular.

The weak performance of infrastructure investment reflects the financial difficulties faced by most of the region's governments since the external debt crisis that erupted in 1982. The need to make fiscal adjustments, compounded by external debt service, led countries to significantly cut their public expenditure, particularly investment.

There is sufficient evidence to state that, faced with fiscal crises in the 1990s, Latin American finance ministries and governments found it easier to suspend or cancel the implementation of major infrastructure projects, rather than reduce external debt service payments, or cut pensions or public-sector pay.

Accordingly, between 1988 and 1998, public investment in infrastructure decreased from 3\% to $1.8 \%$ of GDP in Latin America, falling below the level needed to catch up the so-called Asian "tigers" (Fay and Morrison, 2005). The most recent data confirm the downward trend: in 2002-2006, annual average public investment in infrastructure in the same group of countries was equivalent to just $0.6 \%$ of GDP, which means that public investment in the sector in that period was just one fifth of what it was in the early 1980 s.

These figures show that the decline in public investment was particularly steep in the land transport and energy sectors. In the first case, public investment fell from $0.91 \%$ of GDP (annual average for the period $1980-1985$ ) to $0.16 \%$ (annual average for 1996-2001), which reflects the low priority given by the region's largest countries to this type of infrastructure in policy in the second half of the 1990s. This decline was not offset by greater private investment, which only grew from $0.15 \%$ of GDP to $0.20 \%$, as noted below. As a result, total investment in that area declined sharply (see figure 1).

The drop in public investment in the energy sector (from $1.64 \%$ to $0.31 \%$ of GDP) basically reflects the privatization of electric power companies in most of the region's countries, except Mexico, which meant that the State ceased to be a relevant player in this basic infrastructure area. As was the case in land 


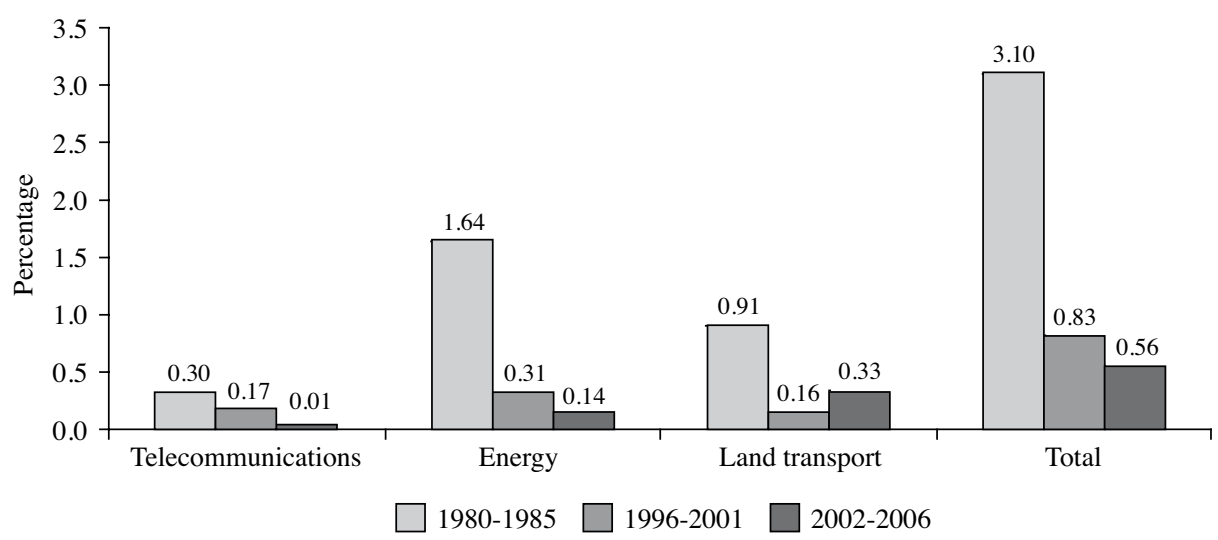

Source: For 1980-1985 and 1996-2001: César Calderón and Luis Servén, "Trends in infrastructure in Latin America, 1980-2001", Working Paper, $\mathrm{N}^{\circ}$ 269, Santiago, Chile, Central Bank of Chile, September 2004. For 2002-2006: prepared by the author on the basis of figures from the World Bank and national statistics.

a Includes Argentina, Brazil, Chile, Colombia, Mexico, Peru and the Plurinational State of Bolivia.

GDP: Gross domestic product.

transport infrastructure, private investment in the energy sector was unable to make up for the decline in public investment.

The most recent data show that the declining trend in public investment gathered pace in the period 20022006 , in both the electric power and telecommunications areas, reflecting the consolidation of privatizations in both activities; but the trend reversed in the case of land transport, which absorbed over half of all public investment in infrastructure in 2002-2006.

The decline in public investment in infrastructure is thus explained not only by the causes identified by Fay and Morrison (2005), who relate it mainly to the fiscal crisis in the region's countries. Apart from the repercussion of privatizations - which meant the State ceased to participate directly in activities such as energy and telecommunications - public investment budgets in the 1990s were cut on the assumption that much of basic infrastructure could be financed and supplied through private investment. This was reflected in policy criteria that guided the profile of the budget in the periods being compared; and much of the debate involved defining the most appropriate institutional and regulatory arrangements for such investment to take place.

Information on the trend of public investment in infrastructure in the region's leading countries provides some very important figures for evaluating the infrastructure deficits in the sector. Figure 4 shows that the decline in public investment in the second half of the 1990s was widespread, occurring in all Latin American countries in the sample. The reduction was particularly sharp in Argentina, Mexico and Peru, where public investment fell to below $1 \%$ of GDP as an annual average for the period 1996-2001. In Brazil, public investment also dropped steeply and barely reached $1 \%$ of GDP in that period. In contrast, the fall was slight in Colombia and moderate in Chile, where investment remained strong (1.72\% of GDP). The situation was partly reversed in some countries in the next five-year period, particularly in Argentina and Mexico, and in the Plurinational State of Bolivia, where public investment in infrastructure grew as part of a major expansion of the corresponding economies, albeit without regaining the levels of the early 1980s.

In fact, despite the recovery, public investment in infrastructure in 2002-2006 did not exceed 1\% of GDP as an annual average, in any of the Latin American countries considered, except for the Plurinational State of Bolivia and Chile. Unlike Argentina, the Plurinational State of Bolivia and Mexico, the downward trend in public investment in infrastructure in the other countries of the sample persisted in the latter five-year period - particularly in Colombia, which had been one of the two countries with the 


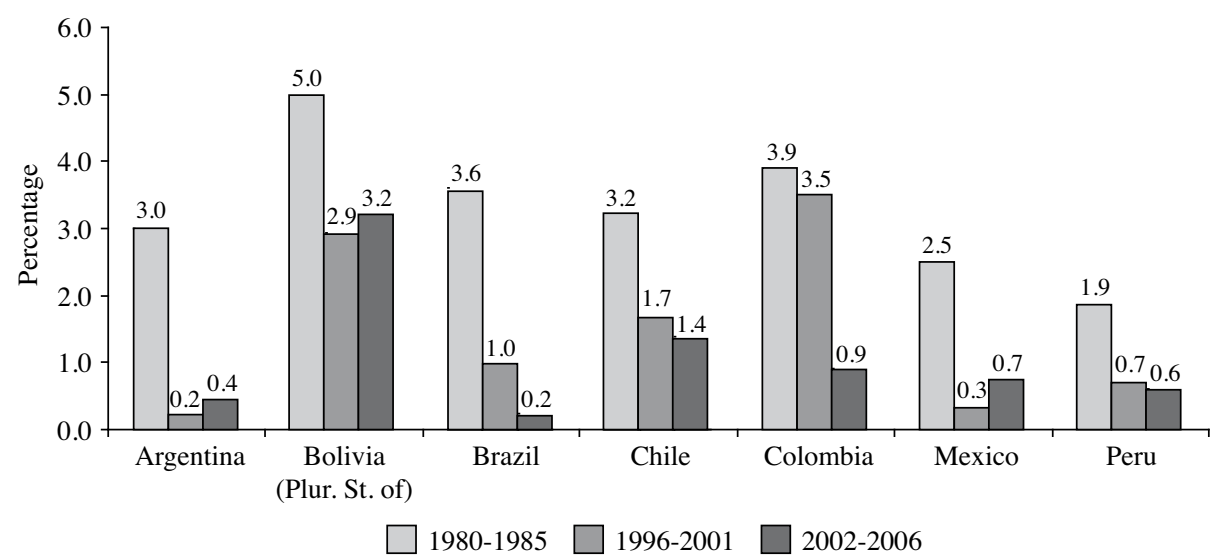

Source: For 1980-1985 and 1996-2001: César Calderón and Luis Servén, "Trends in infrastructure in Latin America, 1980-2001", Working Paper, No. 269, Santiago, Chile, Central Bank of Chile, September 2004. For 2002-2006: prepared by the author on the basis of figures from the World Bank and national statistics.

GDP: Gross domestic product.

highest levels of public investment in the sector until then. This trend also intensified, particularly in Brazil, and somewhat less so in Peru.

The figures reviewed above clearly reveal the particular situation of countries such as Chile and Colombia, which posted infrastructure investment rates close to $6 \%$ of GDP in 1996-2001, as noted in the previous section. It would thus seem that countries with the smallest historical deficits in total infrastructure investment are those that maintained high levels of public investment (Columbia), or suffered smaller reductions (Chile). This was true despite the fact that both countries had introduced far-reaching reforms in the various infrastructure areas, privatizing firms and developing business opportunities for private enterprise, by introducing unconventional participation mechanisms such as highway concessions and other public-private partnership arrangements.

This suggests that public investment not only plays a fundamental role in the sector's development, but its decline to minimal levels could also cause serious investment deficit problems in the sector, owing to the shortcomings and difficulties faced by private enterprise in replacing public investment at the levels required by the growth process.

A sector breakdown of public investment in the two countries confirms this idea. The available data for Chile show that public investment in basic infrastructure was mainly channeled into the transport sector, and this occurred at the same level ( $1 \%$ of GDP) in all five-year periods being compared (see figure 5), thus helping to cushion the sharp drop in private investment between 2002 and 2006, as shown below. This means that the weakening of public investment in infrastructure occurred mainly in telecoms and energy, areas where the State privatized its main assets; and public investment was maintained in areas where the State continues to play a more active role, both in the strategic design of the sector and in the planning of works and their partial or total financing, which depends on the private participation mechanism implemented.

In the sample of economies reviewed, Chile strikes a clear contrast with the region's other countries, except for the Plurinational State of Bolivia, where public investment in land transport infrastructure slumped to almost negligible levels (see figure 6). This adversely affected both conservation and renewal of the existing road infrastructure (in some states of deterioration, the cost of repair may even be greater than building a new road), and also its expansion to meet the growth requirements of the economy as a whole (Bull, 2003). In the most recent period, the effort made by the Chilean government continued to differ significantly from that of other countries in the region, except for the Plurinational State of Bolivia, despite the fact that Argentina, Brazil and Peru significantly increased public investment in land 
FIGURE 5

Chile: public investment in infrastructure areas as

a percentage of GDP, periods 1980-1985, 1996-2001, 2002-2006

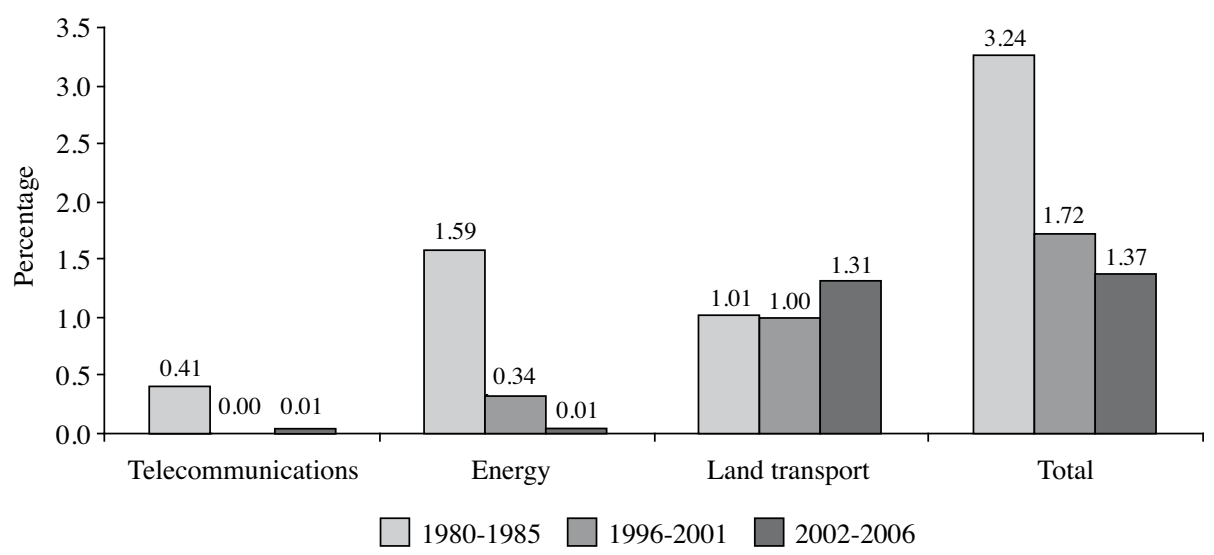

Source: For 1980-1985 and 1996-2001: César Calderón and Luis Servén, "Trends in infrastructure in Latin America, 1980-2001", Working Paper, No. 269, Santiago, Chile, Central Bank of Chile, September 2004. For 2002-2006: prepared by the author on the basis of figures from the World Bank and national statistics.

GDP: Gross domestic product.

FIGURE 6

Latin America (selected countries): public investment in land transport infrastructure as a percentage of GDP, periods 1980-1985, 1996-2001, 2002-2006

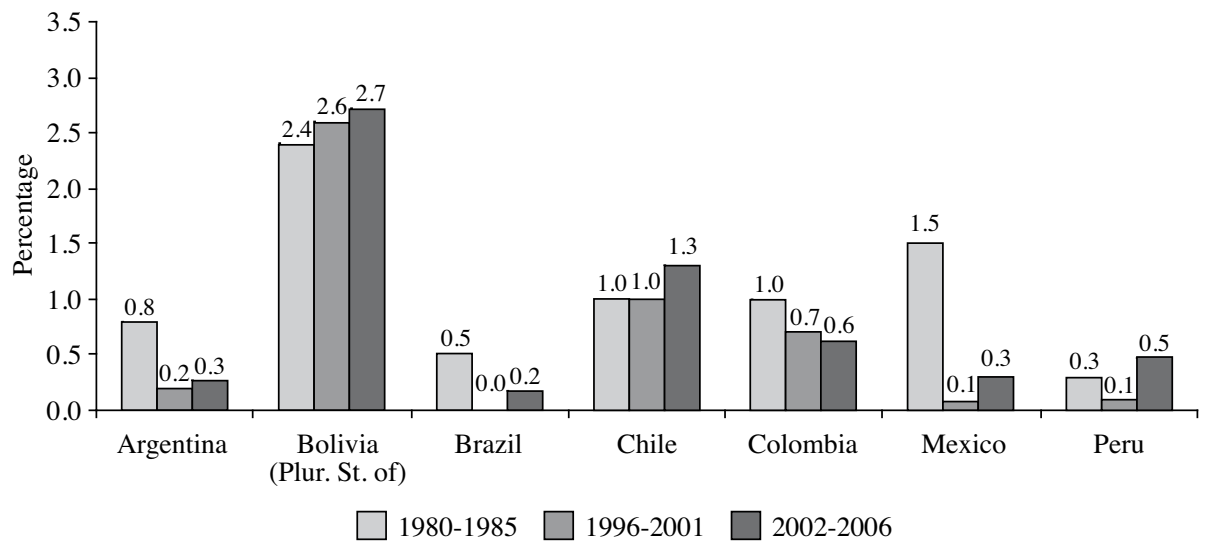

Source: For 1980-1985 and 1996-2001: César Calderón and Luis Servén, "Trends in infrastructure in Latin America, 1980-2001", Working Paper, No. 269, Santiago, Chile, Central Bank of Chile, September 2004. For 2002-2006: prepared by the author on the basis of figures from the World Bank and national statistics.

GDP: Gross domestic product.

transport infrastructure, but without reaching the average levels recorded in 1980-1985.

The specific features of Colombia illustrate the situation even more clearly. Unlike Chile, public investment in infrastructure in Colombia was not targeted on a given sector, although the energy area remained the leading recipient; in general it maintained slightly lower levels in the key areas, but actually grew significantly in telecoms (see figure 7). All of this meant that the reduction in public investment in 


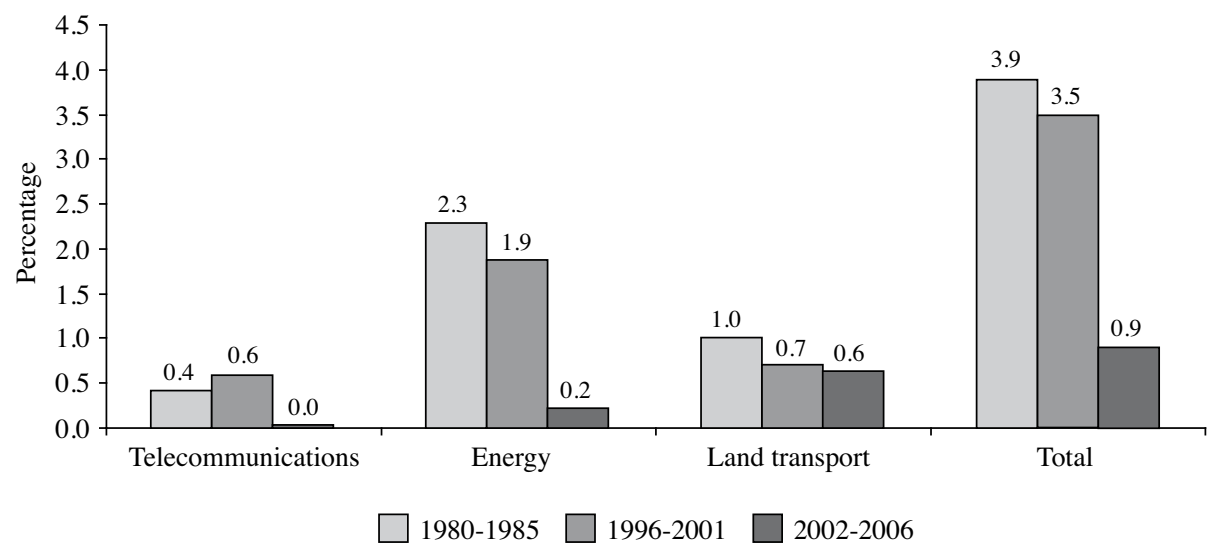

Source: For 1980-1985 and 1996-2001: César Calderón and Luis Servén, "Trends in infrastructure in Latin America, 1980-2001", Working Paper, No. 269, Santiago, Chile, Central Bank of Chile, September 2004. For 2002-2006: prepared by the author on the basis of figures from the World Bank and national statistics.

GDP: Gross domestic product.

basic infrastructure generally differed from the other countries in the region, which, in conjunction with the opening up of the sector to private participation, resulted in an average infrastructure investment rate of $6 \%$.

Nonetheless, in the most recent period (2002-2006), State investment in the sector shrank significantly, mainly owing to the decreased State involvement in the provision of energy and telecommunications services. Nonetheless the Colombian government maintained virtually the same level of investment in land transport, which made that sector the leading recipient of public funds.

In Colombia, this pattern of public investment contributed decisively to the fact that private investment added significantly to total investment in the sector, and was not just a partial substitute for a sluggish public investment. When the latter faltered in the ensuing five-year period, the average investment rate in the sector dropped sharply, in line with the pattern in the other countries in the region.

\section{Trend of private investment}

In general, the 1990s saw major flows of private investment in infrastructure, with particularly strong growth in this process in Latin America, which received half of all private investment in this activity in the developing world. The peak flow of private investment in infrastructure, along with privatizations, concessions and other public-private partnership (PPP) modalities, occurred in 1998, totalling almost US\$ 67 billion. Despite its unprecedented scale in Latin American history, this was only equivalent to $3.87 \%$ of regional GDP and therefore did not succeed in offsetting the cutback in public investment, particularly in the region's larger economies.

In the 1999-2001 triennium, private investment in infrastructure dropped to almost half of the level recorded in 1998, as a consequence of the difficulties faced by some of the region's countries in the energy sector, and the impact of certain macroeconomic imbalances and the completion of the privatization process in the leading Latin American economies. Moreover, this decline intensified in 2002-2003 as a result of the crisis that erupted mainly in South America's Atlantic-coast countries, which seriously affected the behaviour of aggregate demand in those countries - particularly personal incomes and consumer spending as a result of wage compression and higher unemployment - and investment. The subsequent recovery, which began in 2004, only regained pre-2002-2003 crisis investment levels in 2007, and even this achievement may prove ephemeral in the international scenario prevailing since 2008 .

Some analysts prefer to focus the topic from a different standpoint by claiming that the decrease in public investment in infrastructure that occurred 
in the 1990s has been partly offset by greater private participation in the activity. Although true in itself, this line of analysis serves to minimize the drop in investment in the sector and overstate the importance of asset transfers (privatizations and takeovers) — an essential component of private investment that does not have direct repercussions on fixed capital formation (the stock of infrastructure capital).

It should be remembered, however, that privatization processes that began in the region's countries in the late 1980s gave the initial impulse to the introduction of private capital in the infrastructure sector. Roughly $55 \%$ of the value of privatizations undertaken in the 1990s entailed the sale of State assets in sectors that had traditionally been closed to private enterprise (Lora, 2001; Rozas, 2005). Moreover, concessions have been another mechanism for involving private enterprise in the financing, construction and management of infrastructure services, particularly since the mid-1990s. To some extent, these schemes replaced privatizations as a mechanism for attracting private capital, particularly from abroad, which the governments of some of the region's countries used to ease pressure on their respective balance of payments, once the physical assets available for sale had been used up.

Driven by privatizations, particularly in Brazil, and takeover operations in the energy sector, private investment flows in infrastructure grew significantly between 1995 and 1998, from US\$ 14 billion to US\$ 67 billion The highest figures for aggregate investment in the sector were recorded in 1997 and 1998, mainly reflecting the sale of telecommunications and electric power firms in Brazil, the takeover of the Chilean energy group Enersis by Empresa Nacional de Electricidad, S.A. (ENDESA), and the development of highway concessions in several of the region's countries, including Argentina, Chile, Colombia and Mexico.

Private investment in infrastructure increased in nearly all the region's countries, which is unsurprising given that private ownership had been prohibited or restricted in most infrastructure areas until the reforms were implemented. According to World Bank figures, private investment mainly targeted the energy and telecom areas, sectors that absorbed $46.2 \%$ and $32 \%$, respectively, of the total amount invested by private agents in the sector in 1990-2006. In the most recent period, from 2002 to 2006, the trend gathered strength, particularly the telecoms share, which accounted for $52.1 \%$ of private investment in the sector.

The figures presented in the study by Calderón and Servén (2004) downplay the importance of private investors in the region's total infrastructure investment. According to these authors, private investment in the sector grew from $0.61 \%$ of GDP (annual average for

FIGURE 8

Latin America (selected countries): private investment in infrastructure, 1990-2006 (Billions of dollars)

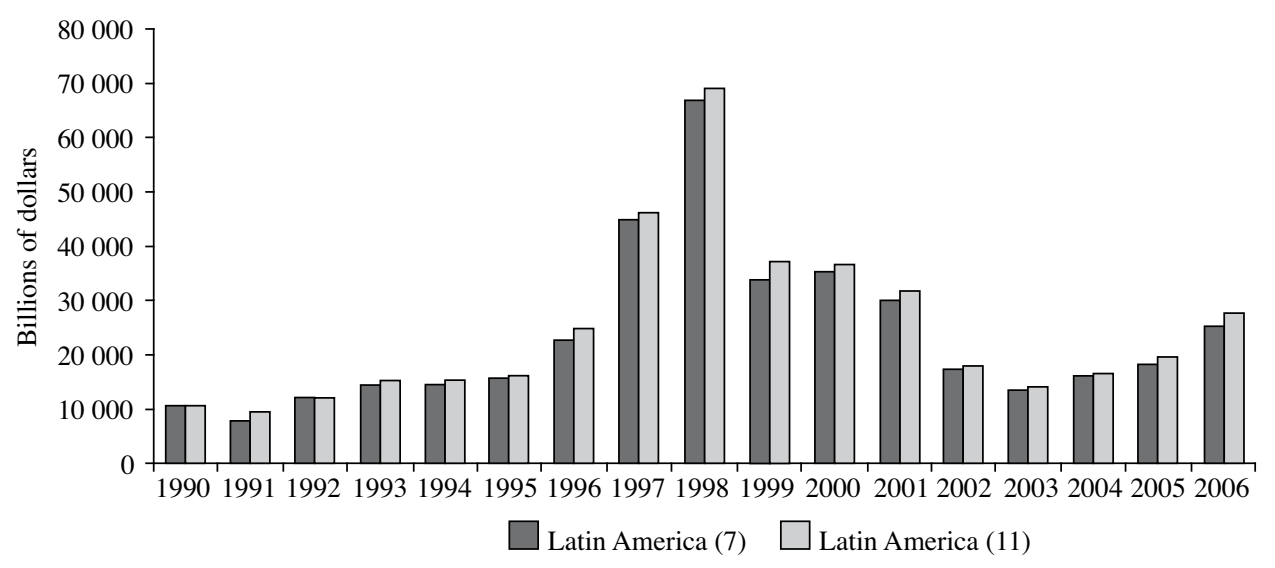

Source: Prepared by the author on the basis of World Bank figures.

Note: Latin America (7) includes Argentina, Brazil, Chile, Colombia, Mexico, Peru and the Plurinational State of Bolivia; Latin America (11) adds the Bolivarian Republic of Venezuela, Ecuador, Paraguay and Uruguay. 
FIGURE 9

Latin America: ${ }^{a}$ distribution of private investment by infrastructure areas in the leading economies

1990-2006

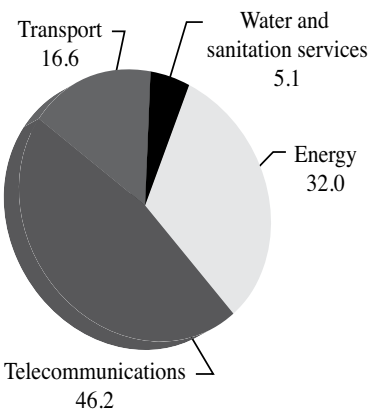

2002-2006

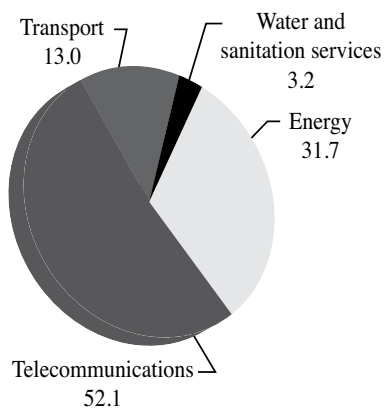

Source: Prepared by the author on the basis of World Bank figures.

a Includes Argentina, Brazil, Chile, Colombia, Mexico, Peru and the Plurinational State of Bolivia.

1980-1985) to $1.41 \%$ of GDP (annual average for 19962001). Although this increase in private investment in infrastructure between the two five-year periods has been seen as reflecting the more active role of private enterprise in sector development (a 131\% increase), it should not be forgotten that the increase amounted to just 0.8 percentage points of GDP - far less than the fall in average public investment between the two periods (-2.27 percentage points). Subsequent data confirm that its share in infrastructure financing was even smaller in the subsequent period (2002-2006), when private investment accounted for just $0.9 \%$ of GDP on average in the region's leading economies.

Private investment grew substantially in the telecoms area, but not in energy or land transport, where private participation has not varied much (see figure 10). In contrast, the relative weight of private investment in telecoms quadrupled, from $0.2 \%$ to $0.8 \%$ of GDP This increase largely reflects the Brazilian government's success in privatizing Telecomunicações Brasileiras, S.A. (TELEBRAS) - a milestone for the sale of State firms in Latin America - and in organizing the mobile phone industry, which triggered a major influx of foreign investment into the sector (Rozas, 2005).

This increased relative weight of private participation in the telecoms sector also encouraged the other countries, particularly Argentina, Chile, Colombia, Mexico and Peru, to increase private investment in the sector, by privatizing the main phone operators. A study of this process (Rozas, 2005) found that the sale of telecom monopolies between 1986 and 2004 generated fiscal revenue of US\$ 42 billion, mostly in the 1990 s.
In the ensuing period, private investment in telecoms fell sharply from $0.77 \%$ to $0.47 \%$ of GDP, reflecting the completion of the privatization of public enterprises in the sector in most of the region's countries. Nonetheless, this activity remains the infrastructure area that has received most private investment, associated with the development of new businesses, together with the skills scenarios provided by the new technologies and progressive deterioration of economies of scale in basic telephony. This reduction occurred in all the countries of the sample analysed, particularly Chile, which has one of the region's highest telephony penetration rates, which suggests that investments in telecommunications have started to reach a ceiling as the corresponding markets steadily mature.

Certainly, it is worth discussing how acceptable it is to consider the investment of capital relating to transfers of ownership of privatized State firms, and which constitute a large part of what some analysts recognise as "private investment", even though such transactions did not have a direct effect on gross capital formation or increasing productive capacity. Strictly speaking, the resources generated by the sale of such firms were most often used to finance current government expenditure rather than increase the sector's infrastructure. It would thus be advisable for countries to differentiate between resources used by investors to buy shares or ownership rights, and those used to constitute, expand, or modernize productive capacity in the enterprise acquired. On that basis, Latin American countries would probably display very different statistics. 
FIGURE 10

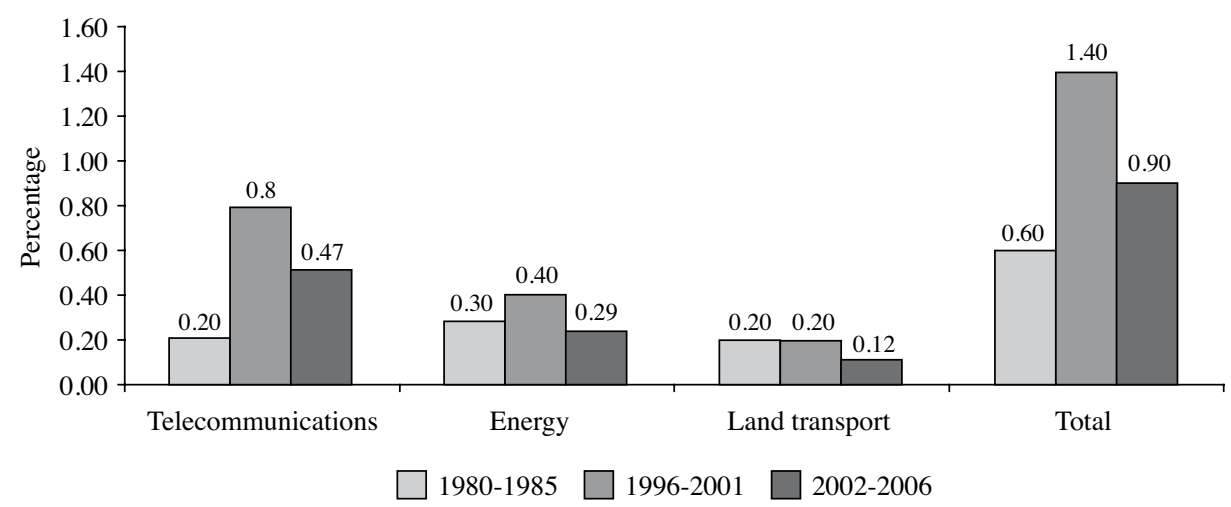

Source: For 1980-1985 and 1996-2001: César Calderón and Luis Servén, "Trends in infrastructure in Latin America, 1980-2001", Working Paper, No. 269, Santiago, Chile, Central Bank of Chile, September 2004. For 2002-2006: prepared by the author on the basis of figures from the World Bank and national statistics.

a Includes Argentina, Brazil, Chile, Colombia, Mexico, Peru and the Plurinational State of Bolivia.

GDP: Gross domestic product.

FIGURE 11

Latin America (selected countries): private investment

in telecommunications infrastructure, as a percentage of GDP

periods 1980-1985, 1996-2001, 2002-2006

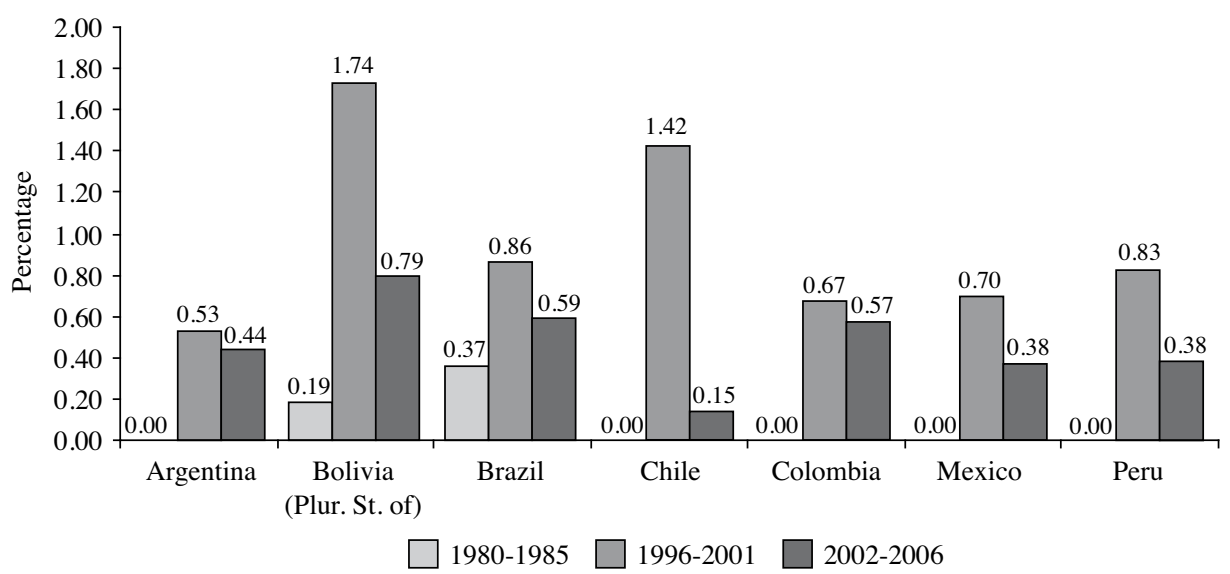

Source: For 1980-1985 and 1996-2001: César Calderón and Luis Servén, "Trends in infrastructure in Latin America, 1980-2001", Working Paper, No. 269, Santiago, Chile, Central Bank of Chile, September 2004. For 2002-2006: prepared by the author on the basis of figures from the World Bank and national statistics.

GDP: Gross domestic product.

It is also worth asking what caused the quadrupling of the relative weight of private enterprise in the average investment made in the telecoms industry, aside from any spurious conclusions that might be obtained from the available figures, when the same did not happen in other infrastructure areas.

ECLAC has argued that the reasons for this difference can be found in the different amounts needed 
to generate an annual unit of revenue (ECLAC, 2004). Using World Bank estimates, ECLAC has shown that telecommunications and energy enterprises, mainly electric power companies, are the infrastructure activities that need the least amount of capital to generate an annual unit of revenue (ECLAC, 2004). Thus, activities such as road building and conservation, and the construction of drinking water supply networks and other sanitation services, are less attractive for private investors, either because of the larger amount they need to invest to generate an annual unit of revenue, or because of the longer time needed to achieve a return on the investment.

This explanation is not applicable to the energy sector, however, where the relative weight of private investment grew only slightly, from $0.31 \%$ of GDP (annual average for the period 1980-1985) to $0.37 \%$ of GDP (annual average for 1996-2001) and to $0.29 \%$
TABLE 1

Financing needed to generate an annual unit of revenue

\begin{tabular}{lc}
\hline & 2002 \\
\hline Energy & 3 \\
Telecommunications & $3-4$ \\
Transport & 7 \\
Water and sanitation & $10-12$ \\
\hline
\end{tabular}

Source: Economic Commission for Latin America and the Caribbean (ECLAC), Productive development in open economies (LC/G.2234(SES.30/3)), Santiago, Chile, 2004 (2004 on the basis of World Bank estimates.

of GDP (annual average for 2002-2006). The likely causes of this performance concern various problems relating to the regulatory framework and organization of international energy markets, as shown by a number of recent studies (Rozas, 2008a).

TABLE2

Latin America: Investment in infrastructure as a percentage of GDP (Percentages)

\begin{tabular}{|c|c|c|c|c|c|c|c|c|c|c|c|c|c|}
\hline \multirow{2}{*}{ Country } & \multirow{2}{*}{ Period } & \multicolumn{3}{|c|}{ Telecommunications } & \multicolumn{3}{|c|}{ Energy } & \multicolumn{3}{|c|}{ Land transport } & \multicolumn{3}{|c|}{ Total infrastructure } \\
\hline & & Total & Public & Private & Total & Public & Private & Total & Public & Private & Total & Public & Private \\
\hline \multirow[t]{3}{*}{ Argentina } & 1980-1985 & 0.33 & 0.33 & 0.00 & 1.57 & 1.57 & 0.00 & 0.84 & 0.84 & 0.00 & 2.96 & 2.96 & 0.00 \\
\hline & $1996-2001$ & 0.53 & 0.00 & 0.53 & 0.40 & 0.03 & 0.36 & 0.32 & 0.15 & 0.17 & 1.45 & 0.22 & 1.24 \\
\hline & $2002-2006$ & 0.44 & 0.00 & 0.44 & 0.46 & 0.12 & 0.34 & 0.32 & 0.27 & 0.04 & 1.26 & 0.42 & 0.83 \\
\hline \multirow[t]{3}{*}{ Brazil } & 1980-1985 & 0.69 & 0.32 & 0.37 & 3.32 & 2.53 & 0.79 & 0.84 & 0.47 & 0.37 & 5.17 & 3.64 & 1.53 \\
\hline & $1996-2001$ & 1.16 & 0.30 & 0.86 & 0.76 & 0.37 & 0.39 & 0.14 & 0.04 & 0.10 & 2.39 & 1.02 & 1.37 \\
\hline & $2002-2006^{\mathrm{a}}$ & 0.60 & 0.01 & 0.59 & 0.43 & 0.00 & 0.43 & 0.23 & 0.18 & 0.05 & 1.31 & 0.23 & 1.08 \\
\hline \multirow[t]{3}{*}{ Chile } & 1980-1985 & 0.41 & 0.41 & 0.00 & 1.59 & 1.59 & 0.00 & 1.01 & 1.01 & 0.00 & 3.24 & 3.24 & 0.00 \\
\hline & $1996-2001$ & 1.42 & 0.00 & 1.42 & 1.78 & 0.34 & 1.44 & 1.96 & 1.00 & 0.96 & 5.58 & 1.72 & 3.86 \\
\hline & $2002-2006$ & 0.16 & 0.01 & 0.15 & 0.14 & 0.01 & 0.13 & 1.79 & 1.31 & 0.48 & 2.28 & 1.37 & 0.91 \\
\hline \multirow[t]{3}{*}{ Colombia } & 1980-1985 & 0.36 & 0.36 & 0.00 & 2.32 & 2.32 & 0.00 & 0.99 & 0.99 & 0.00 & 3.85 & 3.85 & 0.00 \\
\hline & $1996-2001$ & 1.25 & 0.58 & 0.67 & 3.32 & 1.91 & 1.41 & 0.89 & 0.69 & 0.21 & 5.76 & 3.48 & 2.28 \\
\hline & $2002-2006$ & 0.60 & 0.02 & 0.57 & 0.28 & 0.21 & 0.07 & 0.84 & 0.63 & 0.20 & 1.88 & 0.92 & 0.96 \\
\hline \multirow[t]{3}{*}{ Mexico } & $1980-1985$ & 0.24 & 0.24 & 0.00 & 0.49 & 0.49 & 0.00 & 1.54 & 1.54 & 0.00 & 2.45 & 2.45 & 0.00 \\
\hline & $1996-2001$ & 0.73 & 0.03 & 0.70 & 0.11 & 0.11 & 0.00 & 0.34 & 0.08 & 0.27 & 1.24 & 0.27 & 0.98 \\
\hline & $2002-2006$ & 0.38 & 0.00 & 0.38 & 0.44 & 0.31 & 0.13 & 0.41 & 0.28 & 0.12 & 1.37 & 0.73 & 0.64 \\
\hline \multirow[t]{3}{*}{ Peru } & 1980-1985 & 0.31 & 0.31 & 0.00 & 1.29 & 1.28 & 0.01 & 0.33 & 0.30 & 0.03 & 1.98 & 1.94 & 0.04 \\
\hline & $1996-2001$ & 1.07 & 0.24 & 0.83 & 0.94 & 0.32 & 0.63 & 0.25 & 0.12 & 0.13 & 2.28 & 0.68 & 1.60 \\
\hline & $2002-2006$ & 0.39 & 0.00 & 0.38 & 0.65 & 0.07 & 0.58 & 0.88 & 0.47 & 0.41 & 2.02 & 0.61 & 1.41 \\
\hline \multirow{4}{*}{$\begin{array}{l}\text { Bolivia } \\
\text { (Plur. St. of)) }\end{array}$} & & & & & & & & & & & & & \\
\hline & $1980-1985$ & 0.89 & 0.70 & 0.19 & 1.90 & 1.75 & 0.14 & 2.81 & 2.40 & 0.41 & 5.79 & 5.04 & 0.76 \\
\hline & $1996-2001$ & 1.74 & 0.00 & 1.74 & 1.75 & 0.22 & 1.53 & 2.78 & 2.61 & 0.17 & 7.28 & 2.93 & 4.35 \\
\hline & $2002-2006$ & 0.80 & 0.00 & 0.79 & 1.66 & 0.17 & 1.49 & 2.71 & 2.71 & 0.00 & 5.50 & 3.21 & 2.29 \\
\hline \multirow[t]{3}{*}{ Average } & $1980-1985$ & 0.45 & 0.30 & 0.15 & 1.95 & 1.64 & 0.31 & 1.06 & 0.91 & 0.15 & 3.71 & 3.10 & 0.61 \\
\hline & $1996-2001$ & 0.94 & 0.17 & 0.77 & 0.71 & 0.31 & 0.37 & 0.36 & 0.16 & 0.20 & 2.24 & 0.83 & 1.41 \\
\hline & $2002-2006$ & 0.47 & 0.01 & 0.47 & 0.43 & 0.14 & 0.29 & 0.45 & 0.33 & 0.12 & 1.46 & 0.56 & 0.90 \\
\hline
\end{tabular}

Source: For 1980-1985 and 1996-2001: César Calderón and Luis Servén, "Trends in infrastructure in Latin America, 1980-2001", Working Paper, No. 269, Santiago, Chile, Central Bank of Chile, September 2004. For 2002-2006: prepared by the author on the basis of World Bank data and national statistics.

a The level of public investment refers to the period 2004-2006.

GDP: Gross domestic product. 
In short, the sharp increase in private investment in infrastructure was targeted on telecommunications - the only activity where it succeeded in replacing public investment and significantly boosting sector development and modernization. In the other activities, the increased relative weight of private enterprise in investment levels was of less significance, which, in a scenario characterized by fiscal austerity policies, resulted in a sharp contraction of infrastructure investment in several of the region's economies, particularly the larger ones.

Despite the shortcomings noted above, policies to promote private investment in the infrastructure industry did succeed in transforming the economic structure of the related services markets. According to Andrés, Foster and Guasch (2006), in the early part of $2000,86 \%$ of telecoms customers, $60 \%$ of electricity customers and $11 \%$ of drinking water customers were served by private firms. This contrasts with the small proportion of customers served by private firms before 1990, estimated at under 3\%.

\section{Multilateral financing}

In the 1990s, multilateral lending agencies significantly cut back on their funding of infrastructure works in Latin America, while increasing loans to improve sector policies and strengthen government institutions.
The reduction in loans to finance infrastructure works generally reflected a policy that prioritized objectives of assisting the sector authorities in each country of the region, to the detriment of the investor role played by the State in the sector. Consequently, the assistance provided focused on designing policies and instruments aimed at multiplying private investment flows in the sector.

This decision was based on a clear diagnostic error from two points of view: Firstly, insufficient importance was attached to creating and conserving infrastructure as a key factor for growth and development, given its effects on the productivity of economic agents and the competitiveness of enterprises, industries, and whole economies. Secondly, the role played by private agents in creating and conserving infrastructure once the main sector assets had been privatized or handed over in concession, was overstated.

In the particular case of the Inter-American Development Bank (IDB), the strategy of providing greater institutional assistance and less participation in multilateral financing intensified strongly in the late 1990s, as shown in the following figure; and the trend was reversed only in 2005. Before that year, lending to governments in the six-year period 1999-2004 declined to a very small fraction of the loans extended in 1997 and 1998. Moreover, credits granted to private firms also shrank in the same period.

FIGURE 12
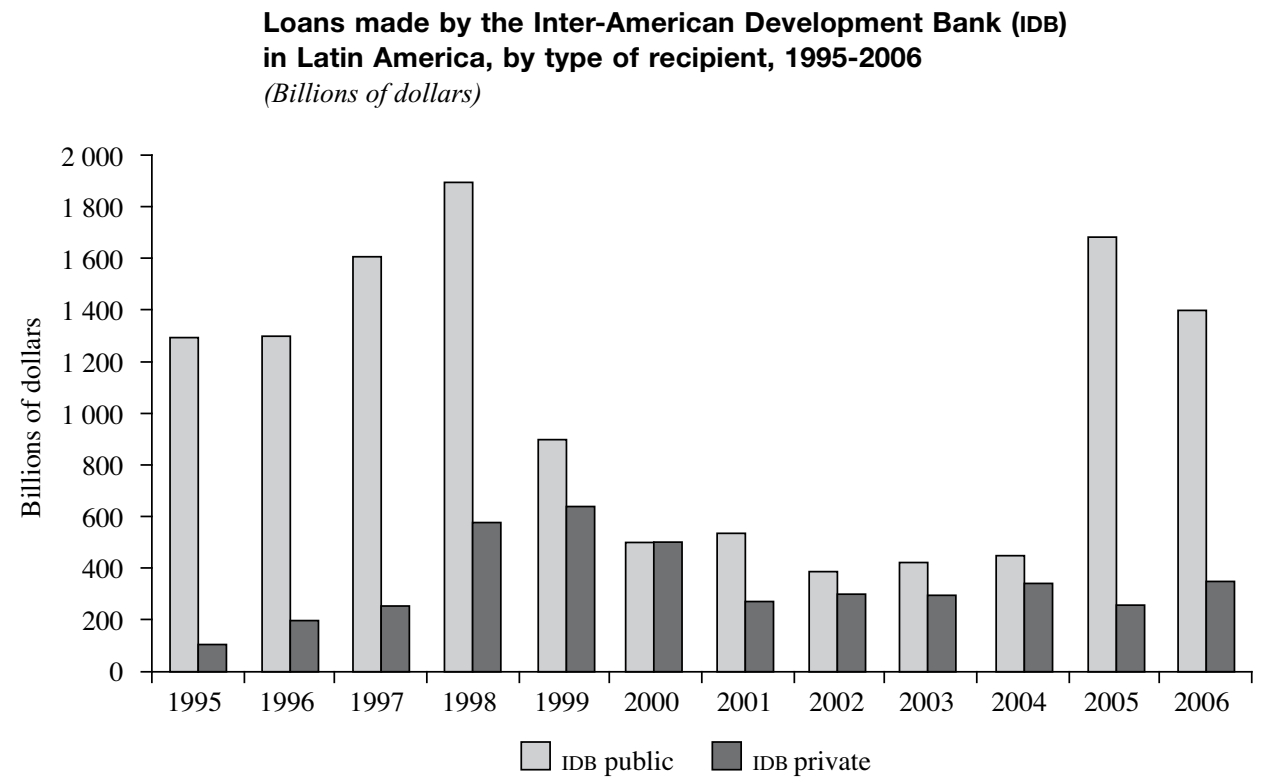

Source: Roberto Vellutini, Financiamento a infraestructura e parceiras público-privadas no setor de energia, Rio de Janeiro, 2007. 
Nonetheless, the region's own multilateral lending agencies performed differently than the World Bank or IDB in this period, implementing a lending policy that was more aligned with the needs of shareholder countries. Such was the case, for example, of the Andean Development Corporation (CAF), which significantly increased its lending in Latin America as from 1990, from US\$ 500 million in 1990 to US\$ 5.5 billion in 2006 (see figure 13).

A large proportion of CAF lending to Latin America took the form of loans to finance infrastructure, a line of business that had begun to develop in 1990. In the five-year period 2002-2006, CAF loans for infrastructure had gained a clear preeminence with respect to other sectors, accounting for $52 \%$ of total loans approved. This is well above the equivalent amounts in earlier periods $(47 \%$ in
$1997-2001 ; 25 \%$ in 1992-1996), thereby revealing the growing importance of infrastructure in the areas of business that the CAF supports (Kogan, 2008). In 2006, the latest year for which information is available, CAF infrastructure loans amounted to just under US $\$ 3$ billion, substantially more than lending by the IDB. Loans targeting the sector have generally followed a rising curve, except in 1999 and 2003, when some of the region's countries faced a variety of difficulties and consequently reduced their demand for credit to finance infrastructure projects. Nonetheless, it should be noted that lending is concentrated a small group of countries (the Bolivarian Republic of Venezuela, Colombia, Ecuador, Peru and the Plurinational State of Bolivia account for $78 \%$ of all loans approved), and is mainly targeted on one sector (transport: 68\%).

FIGURE 13

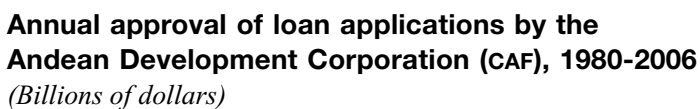

(Billions of dollars)

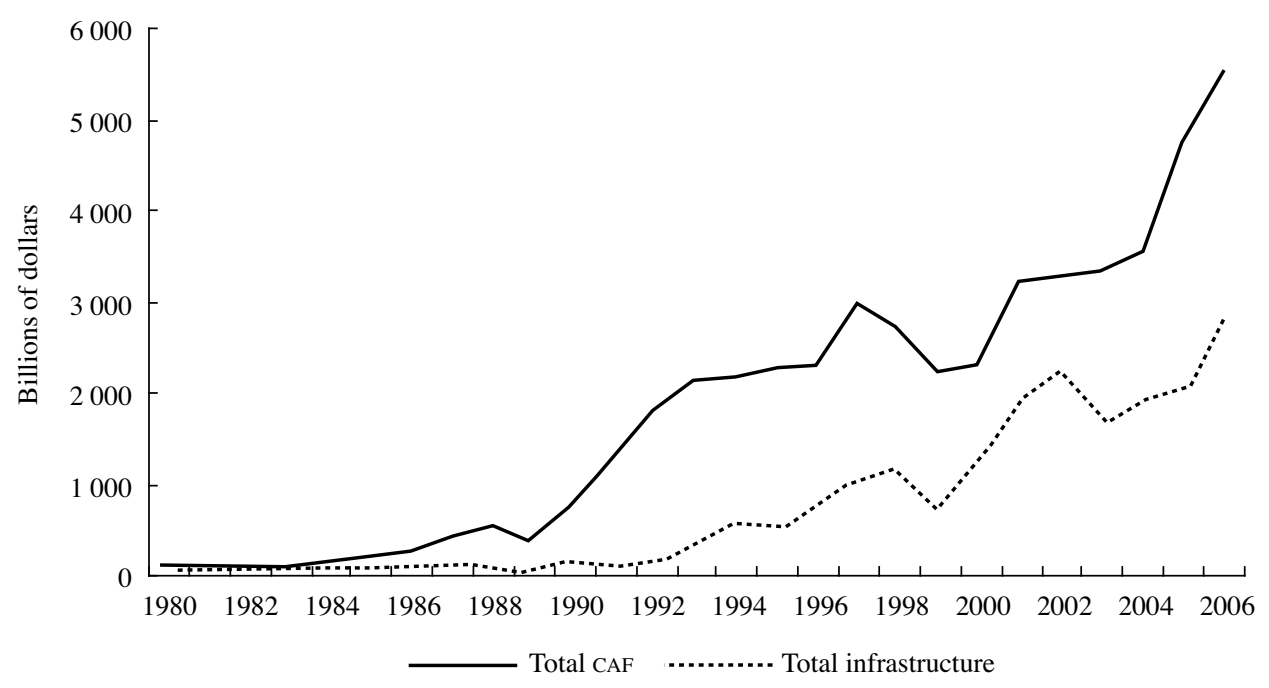

Source: J. Kogan, Financiamiento de la infraestructura: principales desafíos de las alianzas público privadas y de la regulación de los mercados, presentation made at the international seminar entitled "Infraestructura 2020: avances, déficits y desafíos" [Infrastructure 2020, progress, deficits and challenges] (ECLAC, Santiago, Chile, 10 November 2008), 2008. 


\section{III}

\section{Effects of the difficulties in infrastructure investment in Latin America}

The decline of infrastructure investment - particularly in land transport infrastructure, and more intensively in some Latin American countries than in others- has had two types of effect that undermine both economic agents' productivity and the competitiveness of the region's industries and economies, while also impeding an improvement in people's quality of life:

(i) A growing deficit in the stock of infrastructure and in the provision of services, compared not only to developed countries, but also to other developing (or emerging) economies which in the early 1970s had lower levels of service provision than those of Latin America; and

(ii) The drop in investment in the various infrastructure areas, except for telecommunications, has had various effects on the quality of the services provided, which are also seen by users as inferior to those in other emerging economies.

\section{Deficit with respect to other emerging economies}

Despite progress achieved in the infrastructure sector in most of the region's countries over the last 25 years, there is a clear deficit with respect to developed countries and the fastest growing countries in Southeast Asia, in terms of the evolution of the stock and quality of infrastructure systems, and in the coverage of public services.

As table 3 shows, differences in the infrastructure capital stock between Latin America and Southeast Asia grew significantly between 1980 and 2005, widening the gap that already existed in favour of Asian countries in the electric power and telecommunications segments, and reversing the advantage that Latin American countries held over their Asian counterparts in land transport.

In the energy area, although Latin American countries increased their power generating capacity per capita by $57.7 \%$ between 1980 and 2000 , and by $80.8 \%$ between 1980 and 2005 , the countries of Southeast Asia grew theirs by $239 \%$ between 1980 and 2000 , and by $300 \%$ between 1980 and 2005 . This meant that the $38.5 \%$ gap that existed in 2005
TABLE 3

Latin America and South-east Asia: ${ }^{b}$ infrastructure capital stock, selected years

\begin{tabular}{|c|c|c|c|c|c|}
\hline & 1980 & 1990 & 1995 & 2000 & 2005 \\
\hline \multicolumn{6}{|l|}{ Energy $^{c}$} \\
\hline Latin America (22) & 0.26 & 0.36 & 0.38 & 0.41 & 0.47 \\
\hline Latin America (7) & 0.27 & 0.34 & 0.36 & 0.40 & 0.47 \\
\hline South-east Asia & 0.36 & 0.67 & 0.84 & 1.22 & 1.44 \\
\hline \multicolumn{6}{|l|}{ Telecommunications ${ }^{\mathrm{d}}$} \\
\hline Latin America (22) & 39.4 & 61.7 & 97.0 & 271.5 & 618.0 \\
\hline Latin America (7) & 41.2 & 64.3 & 100.8 & 287.1 & 647.7 \\
\hline Southeast Asia & 108 & 324.5 & 476.2 & 1232 & 1464.1 \\
\hline \multicolumn{6}{|l|}{ Land transport $\mathrm{e}^{\mathrm{e}}$} \\
\hline Latin America (22) & 1.1 & 1.18 & 0.93 & 0.86 & 0.83 \\
\hline Latin America (7) & & $\ldots$ & $\ldots$ & 0.77 & 0.76 \\
\hline Southeast Asia & 0.58 & 0.87 & 0.95 & 1.71 & 2.06 \\
\hline
\end{tabular}

Source: Prepared by the author on the basis of data obtained from the Energy Information Administration of the Department of Energy of the United States; the International Telecommunications Union (ITU); the International Road Federation (IRF) and the Energy Information Administration, DOE; and the Economic Commission for Latin America and the Caribbean (ECLAC), Desarrollo productivo en economías abiertas (LC/G.2234(SES.30/3)), Santiago, Chile, June 2004.

a Latin America (22 includes Argentina, the Bolivarian Republic of Venezuela, Brazil, Chile, Colombia, Costa Rica, Ecuador, El Salvador, Guatemala, Guyana, Haiti, Honduras, Jamaica, Mexico, Nicaragua, Panama, Paraguay, Peru, the Plurinational State of Bolivia, Suriname, Trinidad and Tobago, Uruguay and Latin America (7) includes Argentina, Brazil, Chile, Mexico, Peru and the Plurinational State of Bolivia.

b Southeast Asia includes the Republic of Korea, Hong Kong (Special Administrative Region of China), Singapore and Taiwan Province of China.

c Measured as generating capacity in kilowatt per capita.

d Measured as the number of fixed and cellular phones (since 1995) for every 1,000 inhabitants.

e Measured as kilometres of paved roads per capita.

widened to $197.6 \%$ in 2000 and to $206.4 \%$ in 2005 (see figure 14).

In other words, the countries of Southeast Asia easily outpaced their Latin American counterparts in 1980-2005 in terms of increasing their electric-power generating capacity, to the point where in 2005, their generating capacity was triple that of Latin American countries, compared to an advantage of just $36 \%$ in 1980 . 
The trend has been similar in the telecoms area, although with a number of significant differences owing to the tendency for the widening gap between the two groups of countries to be reversed.

By the early 1980s, Southeast Asian countries had already achieved sufficiently greater development than their Latin American counterparts in this activity, with a connectivity difference of $162.4 \%$ between the two groups of countries (see figure 14). At that time, Latin America had a telephone density of just 4.1 telephone line subscribers for every 100 inhabitants, while the equivalent figure in Southeast Asian countries was already of 10.1 .

This gap widened significantly in the 1980 s, as a result of the rapid development of this activity in Southeast Asian countries (200.5\%), four times the expansion of telecommunications in Latin America during that period (56.6\%), to establish a $405 \%$ gap between their development levels. Thus, whereas in Latin America, phone density increased to 6.2 subscribers per 100 inhabitants, in Southeast Asian countries, the equivalent figure grew to 32.4.

Since then, slowly to start with and later more quickly, the gap narrowed significantly in the first five years of the 2000 decade, to $126 \%$, which was less than in 1980 (see figure 14). Nonetheless, despite this reduction, the countries of Southeast Asia still had more than double the number of phone line subscribers per 100 inhabitants recorded in Latin America in late 2005, and consequently displayed significantly higher connectivity in an area that is essential for modernizing each country's productive and commercial structures.

The facile explanation that tends to be offered for this significant reduction in the gap since 1990, and since 2000 in particular, highlights private participation and accords a primary role to privatization of the sector in many of the region's countries. Clearly, that process has been important in countries such as Argentina, Brazil and Chile; but in others, such as the Bolivarian Republic of Venezuela and Panama, privatization has not had the desired effect. In contrast, some countries that maintained the original structure of their phone industry have also achieved rapid rates of expansion of their telephone connectivity, such as Costa Rica and Uruguay, although others countries that also chose to maintain the State monopoly have seen a significant retreat (Rozas, 2005; 2008a).

The backdrop to the narrowing of the gap would seem to stem from two groups of factors: the first linked to the far-reaching productive restructuring experienced by the telecoms industry in the last decade; and the second related to the forms of market organization that were made possible following the productive restructuring of the activity. Introduction of fibre optics, particularly broadband, not only lowered the cost of voice transmission to levels unimaginable in the previous period; but it also made it possible to transmit images and data, resulting in a diversification of the traditional telephony business, which rapidly

FIGURE 14

Infrastructure gaps between Latin America and Southeast Asia by activity, 1980-2005 (Percentages)

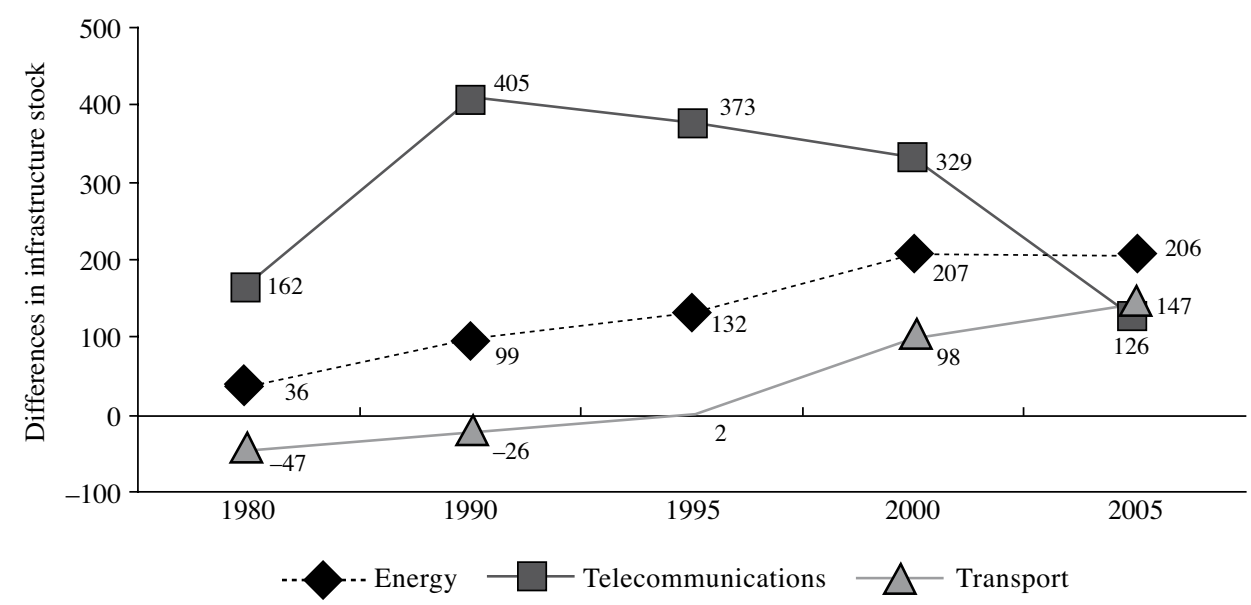

Source: Prepared by the author on the basis of the data shown in table 3. 
extended to pay TV and Internet service provision, generating significant economies of scope and new revenue sources for fixed telephony operators.

It also caused a mass expansion of mobile telephony through the introduction of the callingparty-pays and prepayment systems as modalities for collecting revenue and expanding the business. The main effects of these developments were the rapid erosion of economies of scale and the appearance of market niches in which it was possible for several players to participate simultaneously under competitive conditions, sometimes very fierce, which led to progressive increases in investment levels aimed at penetrating market and/or defending positions and developing new products. All of this led to an expansion and diversification of the supply of telecom services to levels that make its development self-sustaining, irrespective of the public or private origin of the capital of the operating firms.

Unlike what happened in the telecoms industry, the available information shows that the development of transport infrastructure in Latin America - probably the area that felt the reduction of investment between 1980 and 2001 most severely — lags far behind that of other emerging economies. In 1980, the number of kilometres of paved roads per inhabitant in Latin America (1.10) was almost double the equivalent figure in the Southeast Asian economies (0.58); by 2000, however, the situation had reversed in favour of the Asian economies, which now had over 50\% more kilometres paved per inhabitant than the Latin American economies. Worse still: in Latin America, the number of kilometres of paved roads per inhabitant decreased in absolute terms, from 1.10 in 1980 to 0.86 in 2000. This largely shows that Latin American countries not only failed to create new infrastructure, but also were unable to adequately conserve existing infrastructure during the period under analysis. This trend may even have accentuated in the first five years of the 2000 decade, owing to the fiscal difficulties affecting several of the region's countries.

\section{Lower-quality infrastructure}

One of the consequences of inadequate infrastructure investment in the region's countries over the last two or three decades concerns the quality of the services provided, which are below the international standards prevailing not only in developed countries but also in other emerging economies. While there are clearly no objective indicators for this variable - a complex problem in itself that contains many dimensions in each of the basic infrastructure areas - it is possible to gain a rough idea from the country ranking prepared by the World Economic Forum, based on a global index of the quality of infrastructure services.

According to this ranking, the countries of Southeast Asia, including recently industrialized economies, are generally considered to have betterquality indices than Latin American countries. The former group are ranked between positions 3 and 28 , with scores of between 6.6 and 5.1 points. In contrast, no Latin American country is among the 28 highest ranked countries, and their scores vary between 1.9 and 5 , which puts them in places 30 to 129 (see table 4).

The best rated Latin American country is Chile (in 30th place), whose infrastructure services received five points, immediately behind Thailand, the lowest rated recently industrialized Asian economy. Much further behind come Uruguay and Argentina (61st and 80th, respectively) with ratings of 3.7 and 3.1 points.

This is a particularly worrying situation for Latin American countries: the quality of infrastructure services is not only seen as inferior to that of Asian countries, but also it is rated worse in absolute terms, except in Chile.

TABLE 4

Index of the quality of infrastructure in Asian and Latin American economies, 2007

\begin{tabular}{lcc}
\hline Country & Rating & $\begin{array}{c}\text { Average } \\
\text { score }\end{array}$ \\
\hline Singapore & 3 & 60.6 \\
Hong Kong (Special Administrative & & \\
Region of China) & 8 & 60.2 \\
Malaysia & 18 & 50.7 \\
Republic of Korea & 19 & 50.6 \\
Taiwan Province of China & 22 & 5.4 \\
Thailand & 28 & 5.1 \\
Chile & 30 & 5.0 \\
Uruguay & 61 & 3.7 \\
Argentina & 80 & 3.1 \\
Colombia & 89 & 2.8 \\
Suriname & 91 & 2.8 \\
Ecuador & 92 & 2.8 \\
Brazil & 97 & 2.7 \\
Guyana & 100 & 2.7 \\
Peru & 104 & 2.5 \\
Venezuela (Bol. Rep. of) & 105 & 2.5 \\
Bolivia (Plur. St. of) & 123 & 2.1 \\
Paraguay & 129 & 1.9 \\
\hline
\end{tabular}

Source: M. Porter, Klaus Schwab and X. Sala-i-Martin, The Global Competitiveness Report 2007-2008, Nueva York, Palgrave Macmillan, 2007. 
FIGURE 15

\section{Quality of highway infrastructure}

(7= better and $1=$ worse $)$

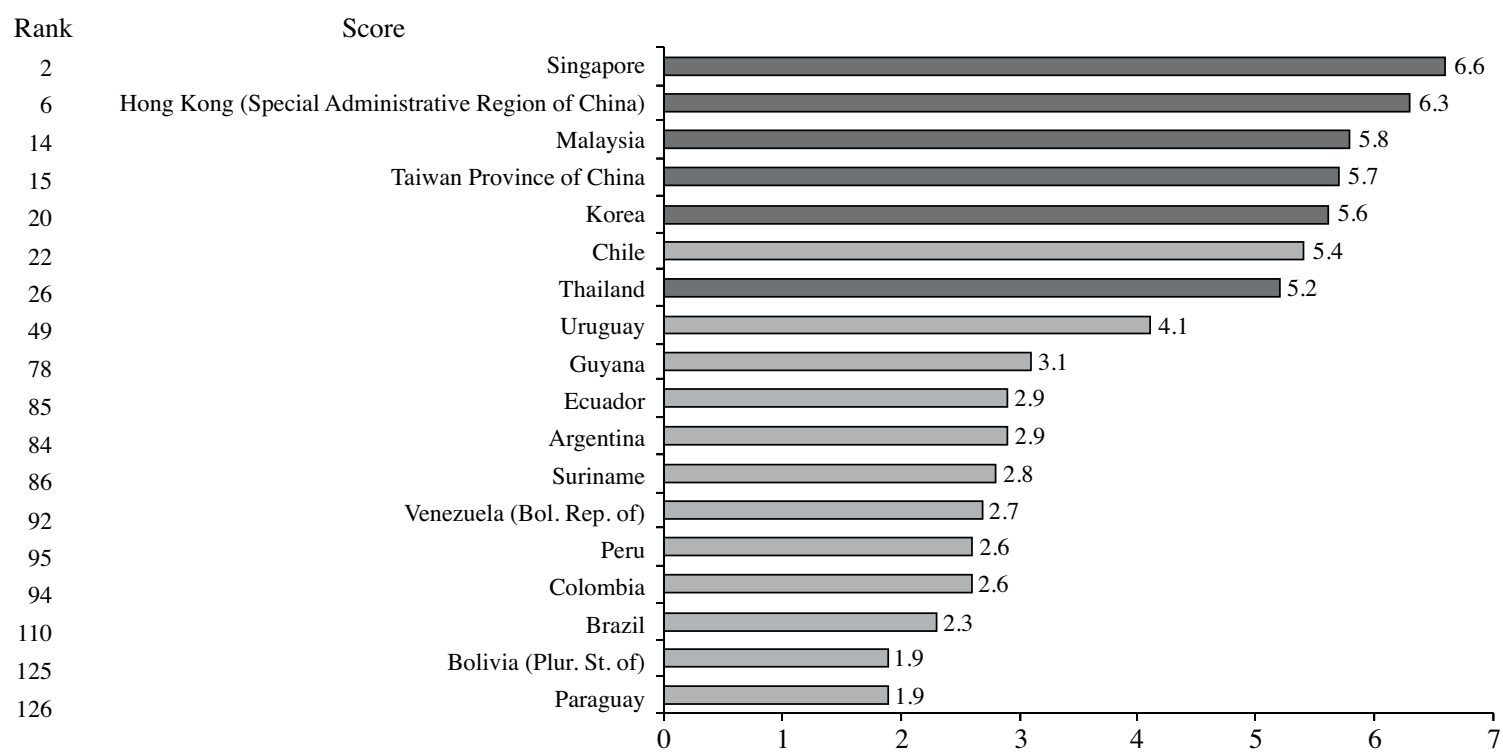

Source: M. Porter, Klaus Schwab and X. Sala-i-Martin, The Global Competitiveness Report 2007-2008, Nueva York, Palgrave Macmillan, 2007.

FIGURE 16

\section{Quality of raiway infrastructure}

(7= better and $1=$ worse $)$

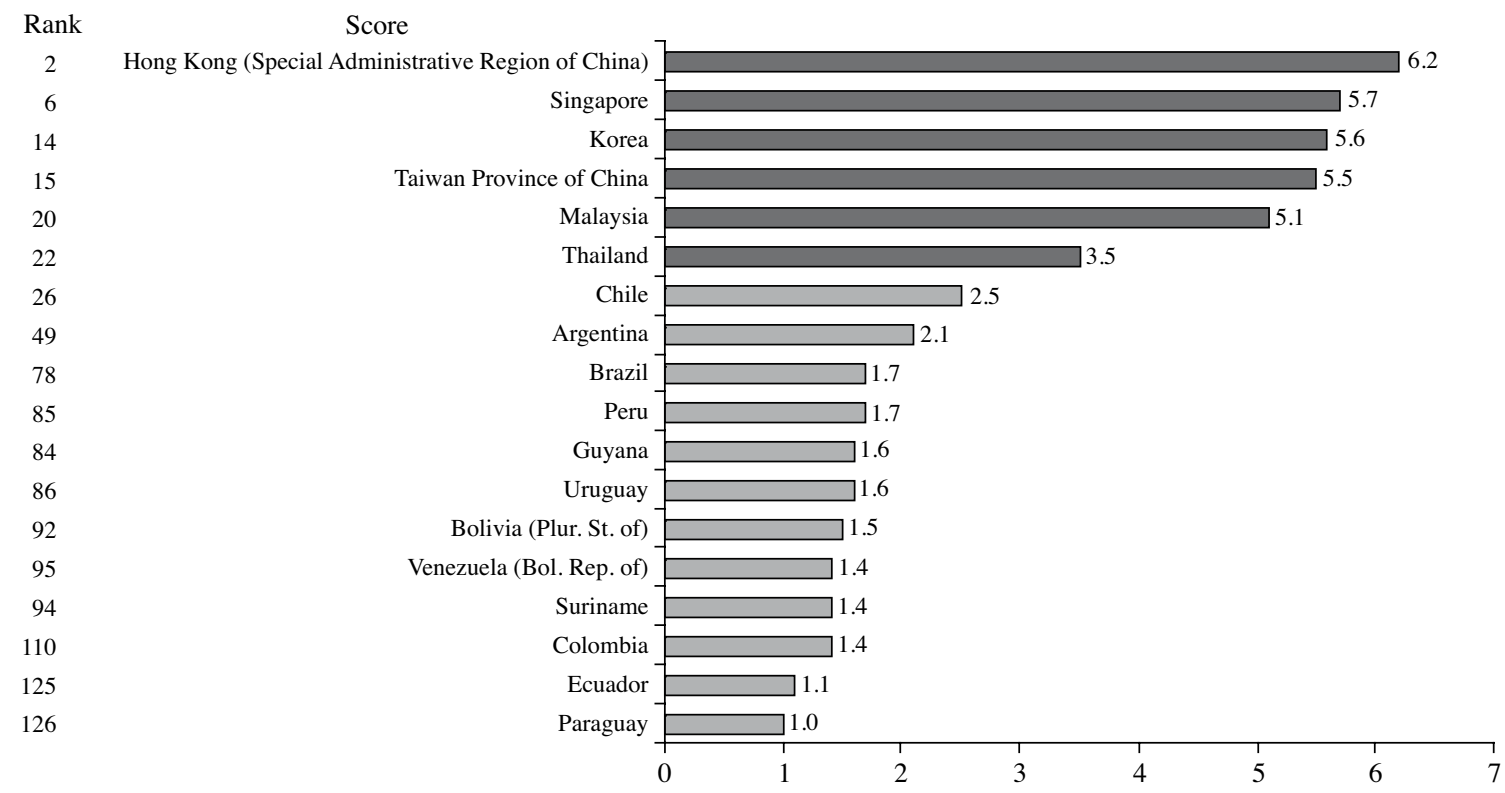

Source: M. Porter, Klaus Schwab and X. Sala-i-Martin, The Global Competitiveness Report 2007-2008, Nueva York, Palgrave Macmillan, 2007. 
FIGURE 17

\section{Quality of port infrastructure}

$(7=$ better and $1=$ worse $)$

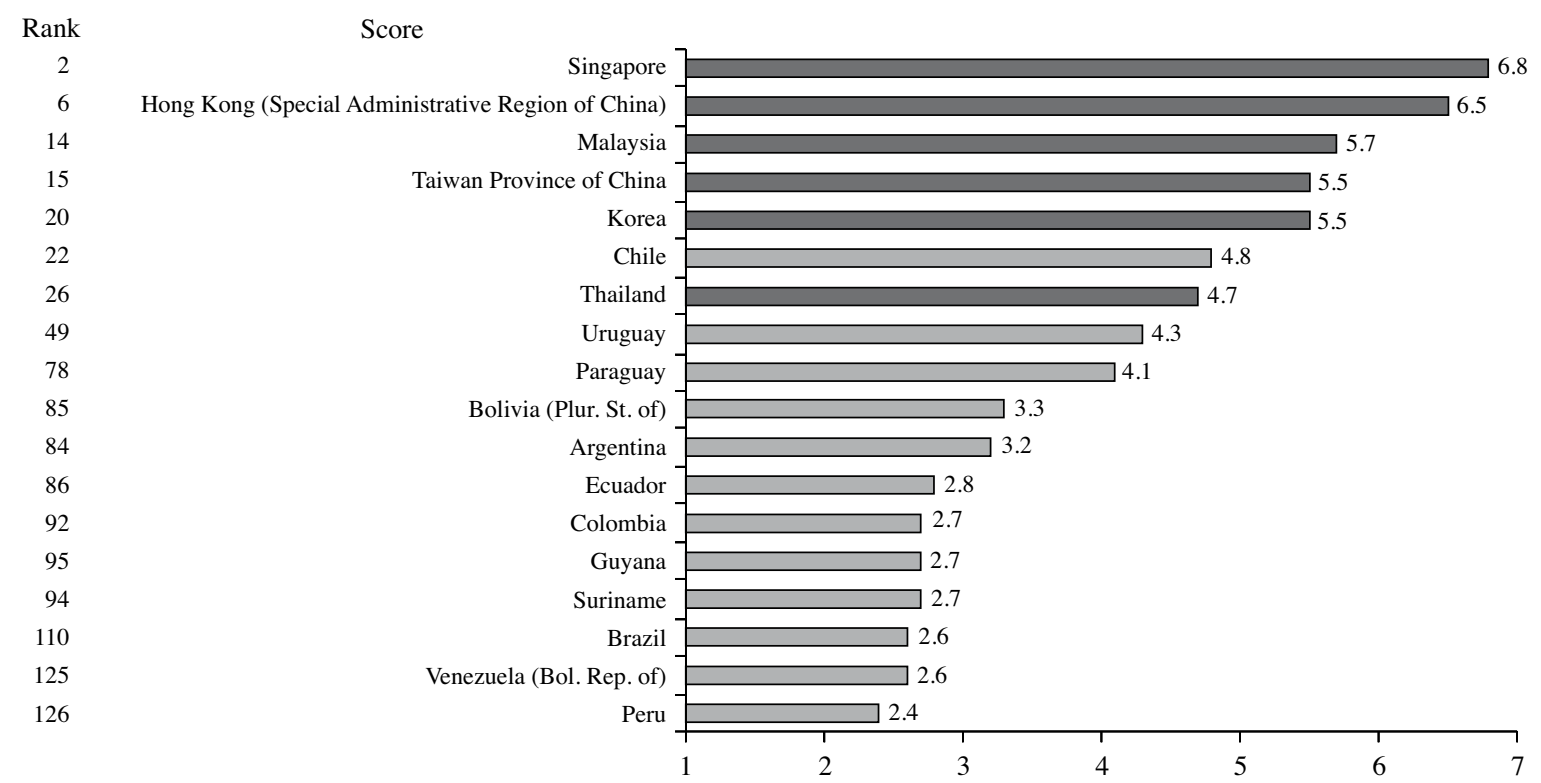

Source: M. Porter, Klaus Schwab and X. Sala-i-Martin, The Global Competitiveness Report 2007-2008, Nueva York, Palgrave Macmillan, 2007.

FIGURE 18

\section{Quality of air transport infrastructure}

$(7=$ better and $1=$ worse $)$

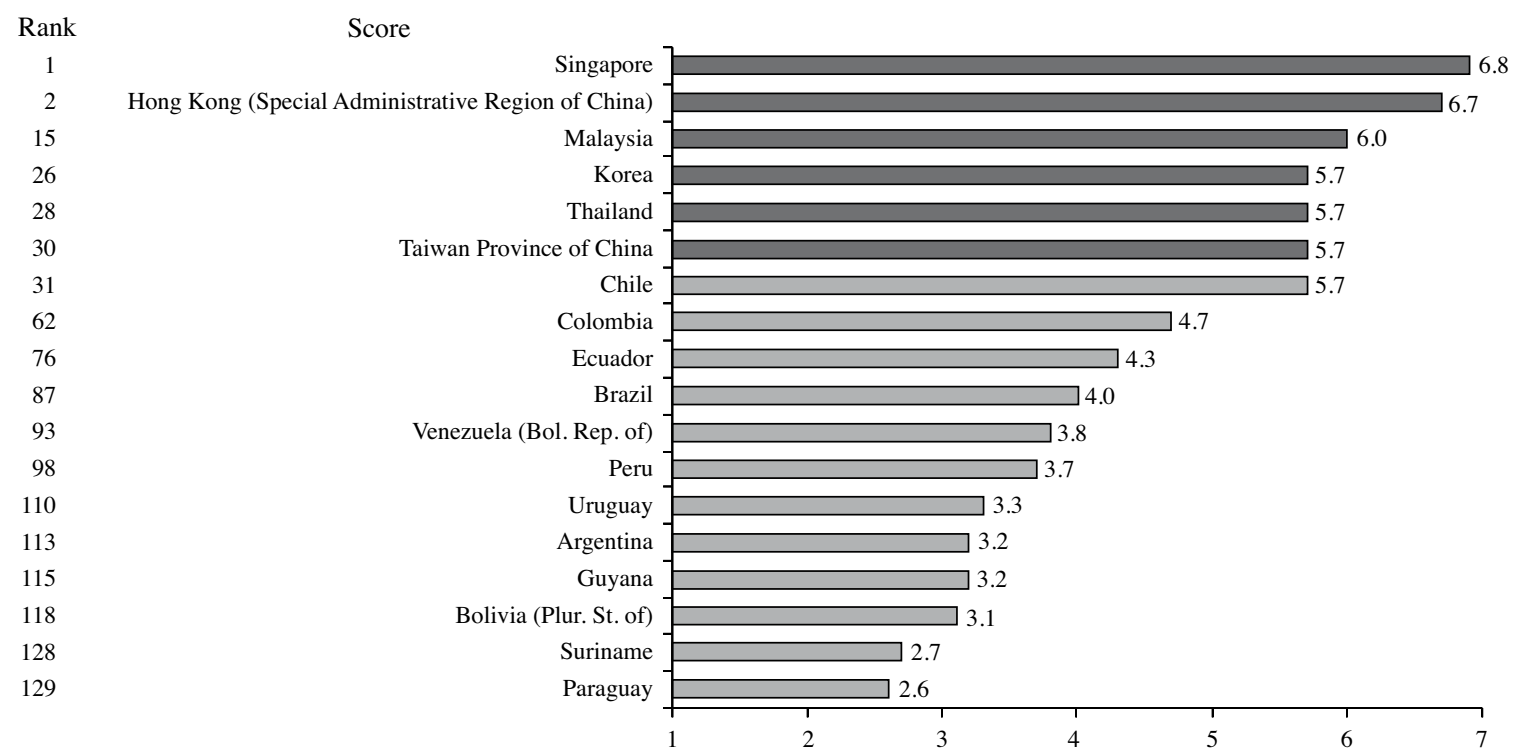

Source: M. Porter, Klaus Schwab and X. Sala-i-Martin, The Global Competitiveness Report 2007-2008, Nueva York, Palgrave Macmillan, 2007. 
FIGURE 19

\section{Quality of telephony infrastructure}

( $7=$ better and $1=$ worse $)$

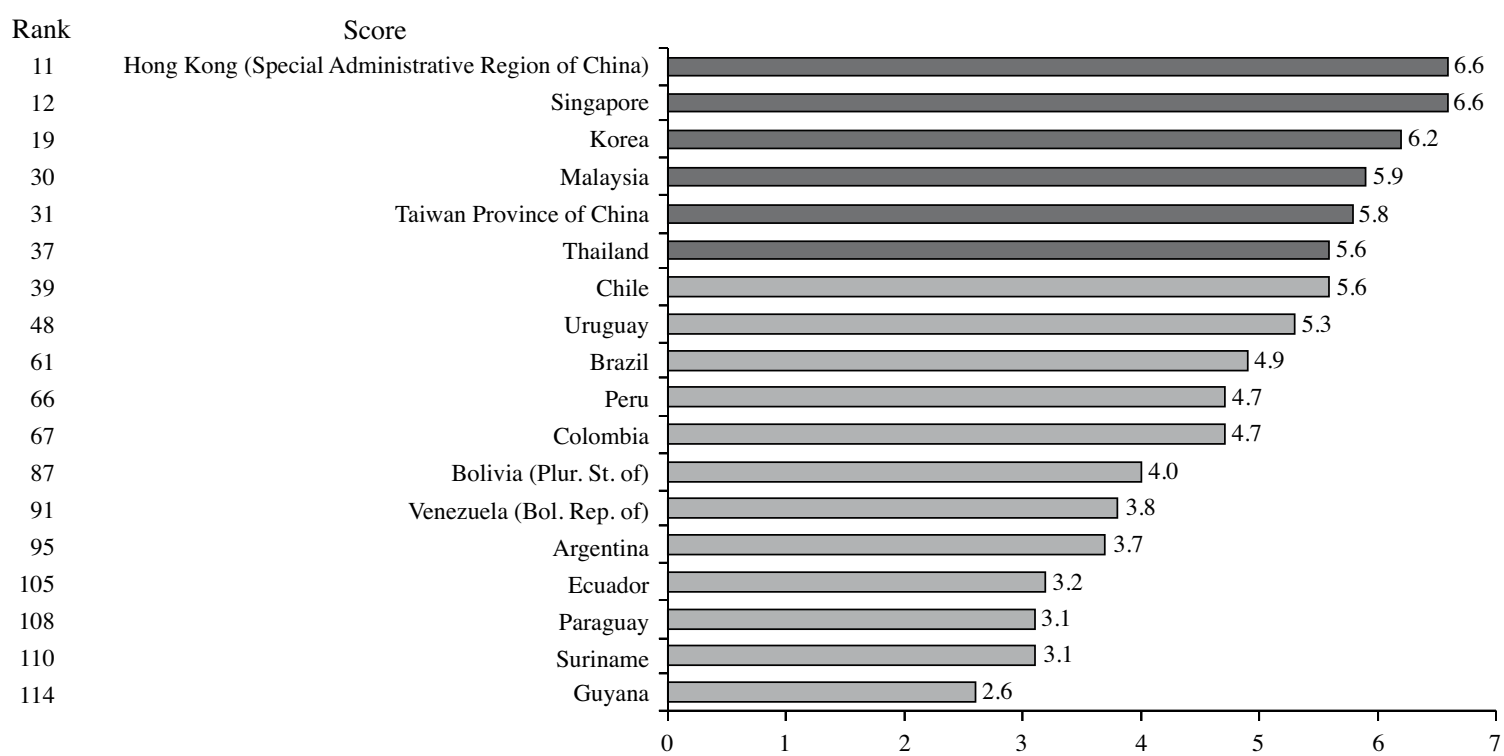

Source: M. Porter, Klaus Schwab and X. Sala-i-Martin, The Global Competitiveness Report 2007-2008, Nueva York, Palgrave Macmillan, 2007.

FIGURE 20

\section{Quality of electric power supply}

$(7=$ better and $1=$ worse $)$

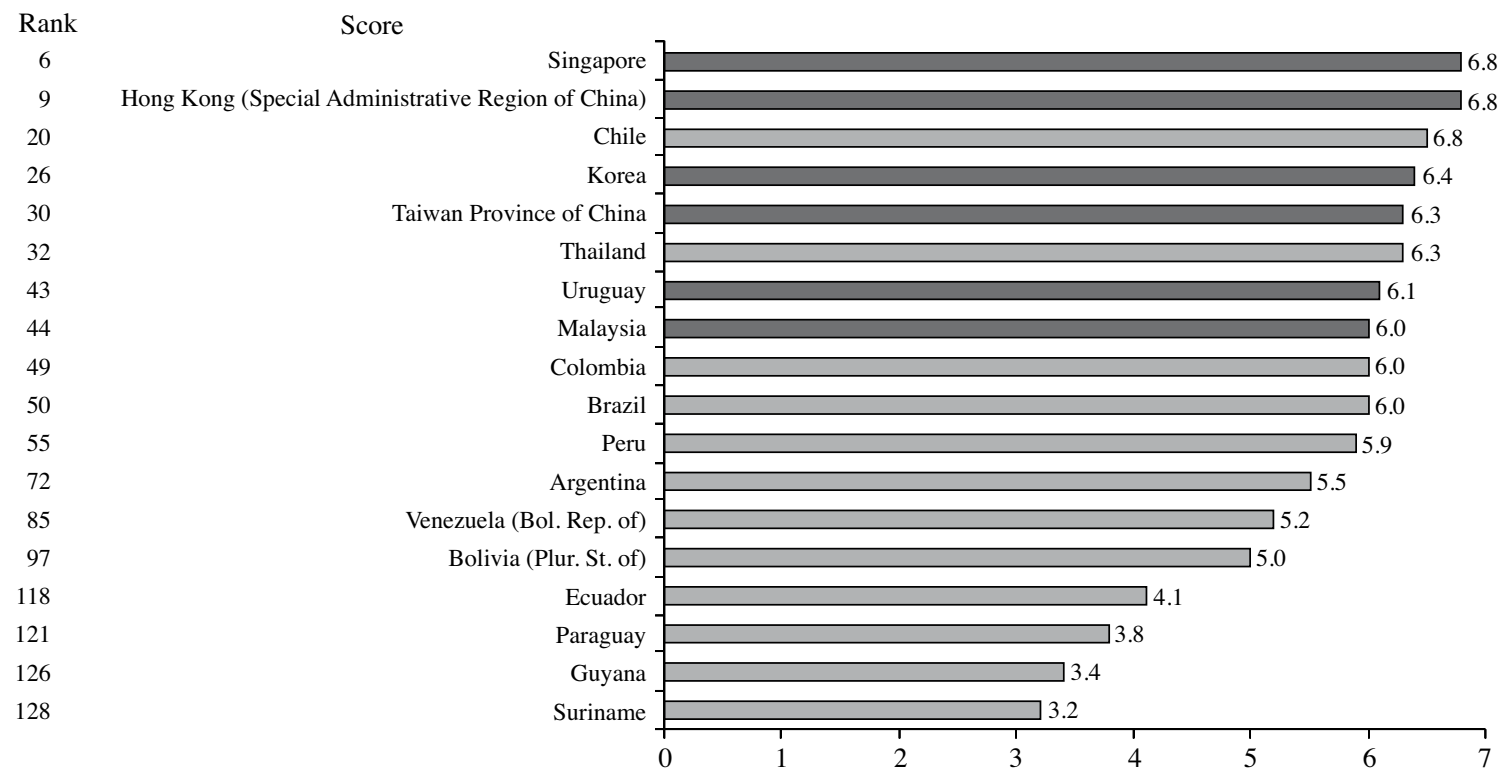

Source: M. Porter, Klaus Schwab and X. Sala-i-Martin, The Global Competitiveness Report 2007-2008, Nueva York, Palgrave Macmillan, 2007. 
The data on specific infrastructure services display a broadly similar trend. As shown in the figures presented on the previous page, road, railway, port, air transport and telecommunications infrastructure in the newly industrialized countries of Southeast Asia display better quality indices than Latin American countries. Chile is the only Latin American country to have obtained better ratings than some Southeast Asian countries in the provision of road and port infrastructure services (better than Thailand). Chile also surpasses the Republic of Korea, Malaysia, Thailand and Taiwan Province of China in terms of the quality of its electricity services, while Uruguay is also better than Malaysia and Thailand in this area.

The figures on the previous page also show that the largest deficit in Latin American countries occurs in railway, port and highway infrastructure, and not in electric power, since eight of the region's countries (Argentina, the Bolivarian Republic of Venezuela, Brazil, Chile, Colombia, Peru, the Plurinational State of Bolivia and Uruguay) obtained scores above five points. Particularly worrying is the perception of railway infrastructure quality, where the best rated Latin American country is Chile, with just 2.5 points. The port infrastructure situation should also be a cause for concern, since no Latin American country obtained a score of over five points. Moreover, Chile was the only country to obtain a rating above this level in road infrastructure. The countries of the Latin American region are clearly lagging in the provision of services in all infrastructure areas, except for the electric power industry, where the gap is substantially smaller. This situation also extends to telecoms, the only sector for which investment rates have risen, as discussed above.

\section{IV}

\section{How can the infrastructure gap be closed?}

Latin America is facing the urgent challenge of narrowing the gap that currently exists between it and the fastest growing economies of Southeast Asia in terms of the availability and quality of infrastructure services, to avoid being overtaken by the growth dynamic of other Asian emerging economies. These already have competitive advantages, which could impair Latin America's possibilities to participate in the new international economic order.

The specialized literature and experts both agree that Latin America needs to increase its annual investment in infrastructure. Fay and Morrison (2005) estimate that if the region's countries invest $0.25 \%$ of GDP each year, they could achieve universal coverage in a reasonable period of time, both in electricity and in water and sanitation, which already have a high level of coverage, but not including wastewater treatment where there is a considerable backlog.

The same authors also point out that adequate maintenance of existing assets in the drinking water, sanitation, electric power, highways, railroads and telecom areas would require the equivalent of $1 \%$ of regional GDP. Lastly, Fay and Morrison estimate that $1.3 \%$ of GDP would be needed to undertake new investments to satisfactorily meet the greater demand that is likely to arise from conservative projections of economic growth.

The Latin American region clearly needs to invest around $2.5 \%$ of GDP in infrastructure to respond to international demand growth, but a slightly higher proportion of GDP (between $4 \%$ and $6 \%$ ) to reach the current standards of the fastest-growing economies of Southeast Asia.

Sector specialists have pointed out in various forums that Latin American countries need to set an annual infrastructure expenditure target of $7 \%$ of GDP, to ensure adequate maintenance of the existing stock and reduce the gap with respect to developed countries and the most dynamic emerging economies of Southeast Asia. According to the World Bank, setting a target infrastructure investment equivalent to $7 \%$ of GDP would not be unrealistic, since that was the level achieved by countries such as China, Indonesia, the Republic of Korea and Malaysia between 1970 and 1990, which today have high infrastructure-development levels. Even countries such as China have invested the equivalent of $9 \%$ of GDP in infrastructure in recent years.

Nonetheless, a target of this type should not be set equally for all Latin American countries, given 
their structural heterogeneity and the different rates of investment in infrastructure they have maintained over the last few years. Clearly, the repercussions on other key economic management variables will be different in a country that raises its infrastructure investment rate from $6 \%$ to $7 \%$ of GDP, compared to another that raises it from $2.1 \%$ to $7 \%$.

Nonetheless, time is of the essence. Since 2003, Latin America has significantly expanded its productive capacity, as reflected in GDP growth rates that are twice the average rate achieved between 1980 and $2002(2.2 \%)$. This means that the demand for infrastructure services has also grown rapidly, outpacing its supply; and demand will continue to grow as the economic upswing as a whole spreads. Given the behaviour of investment in this sector, it is highly likely that significant mismatches will occur between supply and demand for these services, thereby impairing the development possibilities of other productive activities.

Latin America cannot ignore the fact that the expansion of productive capacity has been fuelled mainly by external factors linked to the globalization of the world economy, which is reflected in growing demand for tradable goods, greater liquidity on international financial markets and significant changes in international trade patterns and the terms of trade. The latter have enabled Latin American countries to diversify their trade flows, increase their number of trade partners, expand exports and obtain better prices for their products.

Consequently, the possibility of Latin American countries' maintaining this expansion and growth cycle, and preserving their participation on international markets, depends, among other factors, on a substantial improvement in their basic infrastructure, in terms of both the coverage of and access to the services provided and their quality and prices.

The challenge of overcoming the historical deficit in infrastructure development and narrowing the gaps that separate Latin American from developed countries and the fastest growing countries in Southeast Asia means not only increasing public investment in the sector, but also making a major effort to attract new private investment, which above all should aim to increase the sector's capital stock, rather than merely transfer asset ownership. For that, it is essential to expand and diversify public-private partnership schemes, and to obtain more decisive support for infrastructure development in the region from multilateral lending agencies. These organizations should self-critically review the policies promoted in the last decade and wholeheartedly support infrastructure creation in the region's countries.

The figures mentioned in the foregoing pages highlight the scale of the task facing Latin American countries. First and foremost, governments must accept that the rate of infrastructure investment currently prevailing in the region is clearly insufficient, and that in the best of cases it will only make it possible to conserve existing facilities.

The region's governments must also accept that private investment, generally, has not succeeded in replacing public investment, and has failed to serve as the basis for financial sustenance of the sector's development - except in the telecoms industry in some Latin American countries, thanks to competition and industrial organization policies that were implemented in conjunction with the privatization of the State enterprises that previously dominated the market.

In fact, the figures compiled show that countries with the largest deficit in terms of infrastructure investment compared to international standards are those that most faithfully applied the recommendations of the "Washington Consensus" and which, consequently, cut public investment in the sector most drastically. In contrast, countries that succeeded in raising their infrastructure investment rates are those that maintained high levels of public investment and simultaneously opened up areas for private investment, choosing a heterodox path in relation to those recommendations.

Compared to other expansionary phases in the Latin American economy, the countries of the region are now ideally placed to increase public investment in infrastructure and promote dynamic growth in the sector, given their sound public finances and the balanced state of the main macroeconomic accounts. Latin American economies today generally have higher levels of saving and investment than in the past; moreover, their public finances are healthier, and they have large current account surpluses, while external vulnerability has decreased considerably. This once again places the governments of the region's countries at the centre of the challenges to be faced to improve infrastructure services.

(Original: Spanish) 


\section{Bibliography}

Andrés, Luis, Vivien Foster and José Luis Guasch (2006), “The impact of privatization on firms in the infrastructure sector: the case of electricity distribution in Latin American countries”, Policy Research Working Paper, No. 3936, Washington, D.C., World Bank.

Bull, Alberto (2004), "Concesiones viales en América Latina: situación actual y perspectivas", Recursos naturales $e$ infraestructura series, No. 79 (LC/L.2207-P), Santiago, Chile, Economic Commission for Latin America and the Caribbean (ECLAC), October. United Nations publication, Sales No. S.04.II.G.131.

(2003), "Mejoramiento de la gestión vial con aportes específicos del sector privado", Recursos naturales $e$ infraestructura series, No. 56 (LC/L.1924-P), Santiago, Chile, Economic Commission for Latin America and the Caribbean (ECLAC), June. United Nations publication, Sales No. S.03.II.G.81.

Calderón, César and Luis Servén (2004), "Trends in infrastructure in Latin America, 1980-2001", Documento de trabajo, No. 269, Santiago, Chile, Central Bank of Chile, September.

Canning, D. and P. Pedroni (1999), "The Contribution of Infrastructure to Aggregate Output", Belfast, United Kingdom, Queen's University Belfast, unpublished.

Doerr, Octavio and Ricardo Sánchez (2006), "Indicadores de productividad para la industria portuaria. Aplicación en América Latina y el Caribe", Recursos naturales $e$ infraestructura series, No. 112 (LC/L.2578-P), Santiago, Chile, Economic Commission for Latin America and the Caribbean (ECLAC). United Nations publication, Sales No. S.06.II.G.108.

ECLAC (Economic Comision for Latin America and the Caribbean) (2004), Productive Development in Open Economies (LC/G.2234(SES.30/3)), Santiago, Chile.

Fay, Marianne and Mary Morrison (2005), Infrastructure in Latin America and the Caribbean. Recent Developments and Key Challenges, Washington, D.C., World Bank.

Foster, Vivien (2003), "Mirando hacia atrás: ¿qué funcionó y qué no funcionó en las PPP?" [online] http://www.alide.org.pe/ download/CEDOM/Infraestructura_AS2003/Asociacion $\% 20$ Publico\%20Privada/45mirandoVivien\%20FosterBsAS.pdf

Guash, J.L. and J. Kogan (2001), "Inventories in developing countries: levels and determinants. A red flag for competitiveness and growth", Policy Research Working Paper Series, No. 2552, Washington, D.C., World Bank.
Kogan, J. (2008), "Financiamiento de la infraestructura: principales desafíos de las alianzas público-privadas y de la regulación de los mercados", exhibition at the International Seminar "Infraestructura 2020: avances, déficits y desafíos" (ECLAC, Santiago, Chile, 10 November 2008).

Lora, Eduardo (2007), "Public investment in infrastructure in Latin America”, RES Working Papers, No. 4502, Washington, D.C., Inter-American Development Bank.

(2001), "Structural reforms in Latin America: what has been reformed and how to measure it", RES Working Papers, No. 4287, Washington, D.C., Inter-American Development Bank.

Porter, M., Klaus Schwab and X. Sala-i-Martin (2007), The Global Competitiveness Report 2007-2008, New York, Palgrave Macmillan.

Rozas, Patricio (2008a), "Panorama de las telecomunicaciones en América Latina, 2008", Santiago, Chile, Economic Commission for Latin America and the Caribbean (ECLAC), forthcoming.

(2008b), "La internacionalización de las empresas eléctricas en América Latina: el caso de ENDESA", Recursos naturales e infraestructura series, No. 133 (LC/L.2885-P), Santiago, Chile, Economic Commission for Latin America and the Caribbean (ECLAC). United Nations publication, Sales No. S.08.II.G.22.

(2005), "Privatización, reestructuración industrial y prácticas regulatorias en el sector telecomunicaciones", Recursos naturales e infraestructura series, No. 93 (LC/ L.2331-P), Santiago, Chile, Economic Commission for Latin America and the Caribbean (ECLAC). United Nations publication, Sales No. S.05.II.G.82.

Rozas, Patricio and Ricardo Sánchez (2004), "Desarrollo de infraestructura y crecimiento económico: revisión conceptual", Recursos naturales e infraestructura series, No. 75 (LC/L.2182-P), Santiago, Chile, Economic Commission for Latin America and the Caribbean (ECLAC). United Nations publication, Sales No. S.04.II.G.109.

Sánchez, Ricardo and Gordon Wilmsmeier (2005), "Provisión de infraestructura de transporte en América Latina. Experiencia reciente y problemas observados", Recursos naturales e infraestructura series, No. 94 (LC/L.2360-P), Santiago, Chile, Economic Commission for Latin America and the Caribbean (ECLAC), August. United Nations publication, Sales No. S.05.II.G.86.

Vellutini, Roberto (2007), "Financiamento a infraestructura e parceiras público-privadas no setor de energia", Rio de Janeiro. 